\title{
Original paper \\ Geological position, mineral assemblages and contamination of granitic pegmatites in the Moldanubian Zone, Czech Republic; examples from the Vlastějovice region
}

\author{
Milan NOVÁK*, Tomáš KADLEC, Petr GADAS \\ Department of Geological Sciences, Masaryk University, Kotlářská 2, 61137 Brno, Czech Republic; mnovak@sci.muni.cz \\ ${ }^{*}$ Corresponding author
}

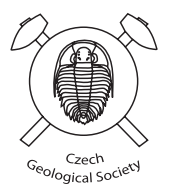

Three groups of pegmatites distinct in their geological position, age, internal structure, mineral assemblages and chemical composition of minerals (tourmaline, amphibole, garnet, and biotite) were distinguished in the Vlastějovice region, Moldanubian Zone: a) tourmaline-bearing pegmatites ( $\mathrm{Qz}+\mathrm{Kfs}+\mathrm{Pl}+\mathrm{Bt}+\mathrm{Ms}+$ Tur) enclosed in the pre-Variscan orthogneiss, b) contaminated amphibole-bearing pegmatites $(\mathrm{Pl}+\mathrm{Qz}+\mathrm{Amp}+\mathrm{Kfs}+$ fluorite + allanite) hosted by the Fe-skarn, and c) tourmaline-bearing pegmatites cutting paragneisses ( $\mathrm{Qz}+\mathrm{Kfs}+\mathrm{Pl}+\mathrm{Bt}+\mathrm{Ms}+\mathrm{Ab}+\mathrm{Tur}+\mathrm{Grt})$ and the Fe-skarn (Qz + Kfs + Pl + Bt + Tur \pm Ab, Amp, Grt, elbaite). The pegmatites enclosed in the orthogneiss show simple internal structure and mineral assemblages, together with low degree of tectonometamorphic overprint. The amphibole-bearing pegmatites, likely anatectic and related to the Variscan MP-HT regional metamorphism, are spatially restricted to the Fe-skarn body and highly variable in shape, size, effects of in situ contamination by $\mathrm{Ca}, \mathrm{Fe} \pm \mathrm{F}$ and $\mathrm{REE}$ from the host Fe-skarn, and degree of hydrothermal overprint.

The tourmaline-bearing pegmatites related to the Variscan magmatic event cut different rocks (paragneisses, Fe-skarn bodies) and belong to the Moldanubian rare-element pegmatite province. They show distinct degree of textural differentiation, geochemical fractionation and external contamination by $\mathrm{Ca}$ and/or $\mathrm{Fe}$ (Ca,Fe-rich Al-poor tourmalines) higher in the less evolved pegmatite bodies in the Fe-skarn. The tourmaline-bearing pegmatites were evidently generated from the granite-pegmatite body in the footwall contact of the Fe-skarn. Degrees of the textural differentiation and geochemical fractionation of the individual tourmaline-bearing pegmatites are comparable to those of the respective parts of the parental Footwall granite-pegmatite body. This observation seems consistent with the model of sequential derivation of pegmatite melts from evolving parental granite. Primitive to highly evolved and usually B-rich pegmatites originated during the Variscan orogeny from the MP $(\sim 0.6-0.7 \mathrm{GPa})$ to the LP conditions ( $\sim 0.2 \mathrm{GPa})$, and manifest that formation of various granitic pegmatites was an integral part of the tectonomagmatic evolution of the region.

Keywords: tourmaline, granitic pegmatites, Fe-skarn, Vlastějovice, Moldanubian Zone

Received: 7 January 2013; accepted: 15 March 2013; handling editor: S. Vrána

\section{Introduction}

Granitic pegmatites are widespread magmatic rocks in the Moldanubian Zone of the Bohemian Massif, Czech Republic, although volumetrically negligible. Several classes, groups, types and subtypes of granitic pegmatites were recognized based on their geological position, internal structure, mineral assemblages and origin by Čech et al. (1981), Čech (1985), Novák et al. (1992, 2012), Novák (2005), and Novák and Cempírek (2010). However, the authors used the different classification schemes of granitic pegmatites relevant at the time (e.g., Vlasov 1952; Ginzburg et al. 1979; Černý 1991a; Černý and Ercit 2005).

The Vlastějovice region (Fig. 1a) is characterized by abundant granitic pegmatite bodies with different shape, size, host-rocks, mineralogy and origin. They are well accessible in large quarries on the Holý vrch and Magdalena Fe-skarn deposits, as well as on outcrops in the
Sázava valley. The Vlastějovice pegmatites thus represent a very good object for a case study of typical granitic pegmatites of the Moldanubian pegmatite province in a relatively small area.

Pegmatites in the Vlastějovice region were divided into several groups and subgroups based on their mineral assemblages, internal structure and degree of contamination. However, the detailed field and laboratory study by the current authors in 2001-2012 have suggested that only three principal groups of granitic pegmatites exist in this region (Kadlec 2007a, 2009): (i) tourmaline-bearing pegmatites enclosed in the orthogneiss, (ii) contaminated amphibole-bearing pegmatites from the Fe-skarn, and (iii) tourmaline-bearing pegmatites cutting Fe-skarn and surrounding paragneisses.

The amphibole-bearing pegmatites cutting the Vlastějovice Fe-skarn and their minerals were studied by numerous authors (e.g., Koutek 1950; Vavřín 1960, 1962; Povondra et al. 1985; Žáček et al. 2003; Ackerman 2005; 
Žáček 2007; Ackerman et al. 2007; Novák and Cempírek 2010 and references therein). On the other hand, common simple tourmaline-bearing types cutting the paragneisses and the Fe-skarn as well as those enclosed in the orthogneiss body were examined only exceptionally (Vavř́n 1960; Staněk and Schnorrer 1983; Ackerman et al. 2007; Kadlec 2007a, 2009).

In this paper we present data for all the main types of Vlastějovice pegmatites, including descriptions of their geological position, internal structure, mineral assemblages as well as chemical composition of selected minerals, namely tourmaline, biotite, amphibole, and garnet. Degrees of geochemical fractionation and external contamination of the individual pegmatite groups as well as their geological position in the tectono-metamorphic evolution of the Moldanubian Zone (see Novák 2005, 2007; Novák and Cempírek 2010; Gadas et al. 2012) are also discussed.

\section{Geological background}

\subsection{Tectono-metamorphic and magmatic evolution of the Moldanubian Zone}

The Moldanubian Zone, the highly metamorphosed core of the Bohemian Massif, represents a crustal (and upper mantle) tectonic collage assembled during the Variscan orogeny and modified by several events of superimposed deformations and high- to low-grade metamorphic recrystallizations. Several tectonic/lithological units were defined (e.g., Fuchs and Matura 1976; Matte et al. 1990; Fiala et al. 1995; Schulmann et al. 2008). (i) Mid-crustal, amphibolite-facies Drosendorf Unit is traditionally divided into the Monotonous and Varied groups. In addition to the dominant high-grade paragneisses, the Varied Group contains numerous intercalations/small bodies of amphibolites, marbles, calc-silicate rocks, orthogneisses, quartzites and graphitic gneisses. The Monotonous Group is composed of migmatized sillimanite-biotite-cordierite paragneisses with subordinate quartzites and amphibolites. (ii) The bottom of the lower crustal/upper mantle Gföhl Unit is formed by MORB-like metabasites, overlain by mainly anatectic orthogneisses (Cooke and O'Brien 2001; Hasalová et al. 2008) and by HP granulites, enclosing minor bodies of pyrope- and spinel-bearing peridotites, garnet pyroxenites and eclogites (e.g., Fiala et al. 1987; O`Brien and Rötzler 2003). (iii) Allochthonous segments of ancient crust in the Moldanubian Zone are represented by the Dobra gneiss $(1.3 \mathrm{Ga}$, Friedl et al. 2004) in Lower Austria and the Světlík orthogneiss (2.1 Ga, Wendt et al. 1993) in southern Bohemia. The Kutná Hora and the Svratka units situated along the NE to $\mathrm{E}$ border of the Moldanubian Zone (Fig. 1a) were correlated by Vrána et al. (2009) and Pertoldová et al. (2010) with the palaeo-Variscan Orlice-Sněžník Unit in the Polish Sudetes. The latter constituted an older frame against which the Moldanubian complex was exhumed.

Two major Variscan tectono-metamorphic events affected the Moldanubian Zone (Finger et al. 2007). a) The Moravo-Moldanubian MP-HT event at $\sim 340-330 \mathrm{Ma}$ includes a polyphase metamorphic evolution. (i) A HPHT event in upper amphibolite to granulite facies at $\mathrm{T}_{\text {max. }} \sim 850-900^{\circ} \mathrm{C}$ and $\mathrm{P}_{\max }=1.2-1.8 \mathrm{GPa}$ was recorded in granulites and eclogites from the Gföhl Unit (e.g. Carswell and O'Brien 1991; Janoušek and Holub 2007). It was more or less overprinted during a rapid decompression by (ii) a MP-HT event at $\mathrm{T}<\sim 700^{\circ} \mathrm{C}$ and $\mathrm{P}$ 0.4-0.6 GPa (e.g., Pertoldová et al. 2009). This stage was very likely connected to partial melting of the rocks. (iii) Contact (periplutonic) LP-HT metamorphism around granitoid plutons (see below) affected their envelope. b) The Bavarian LP-HT event occurred between 326 and $315 \mathrm{Ma}$ and was very likely restricted to the Bavarian Moldanubicum (Finger et al. 2007).

The tectonometamorphic history of the Moldanubian Zone was characterized by extensive Variscan igneous activity at individual stages of the geodynamic evolution, i.e. between Late Devonian to Permian (see Holub et al. 1995; Finger et al. 1997; Timmerman 2008 for overview). The chemistry of Variscan magmas has changed during evolution: (i) subduction-related normal and high-K calc-alkaline suites ( $\sim 370-345 \mathrm{Ma}$ ) (Holub et al. 1997a; Janoušek et al. 2000; Žák et al. 2011) through (ii) (ultra-) potassic, magnesium-rich quartz syenitic to melagranitic plutons - durbachites (Holub 1997) following shortly after exhumation of the high-grade Gföhl Unit to mid-crustal levels (at $340-335 \mathrm{Ma}$ - Holub et al. 1997b; Kröner et al. 2000; Janoušek and Holub 2007; Kusiak et al. 2010; Kotková et al. 2010), and (iii) moderately-strongly peraluminous anatectic granites formed as a consequence of the LP-HT metamorphic event at 331-326 Ma (the Eisgarn and Weinsberg suites) intruding the Moldanubian Zone, and (iv) late small plutons of fine-grained $I$-type granitoids associated with minor diorites at 319-300 Ma (e.g. Liew et al. 1989; Vellmer and Wedepohl 1994; Holub et al. 1995; Gerdes et al. 2000, 2003).

\subsection{Review of granitic pegmatites from the Moldanubian Zone}

\subsubsection{Classification}

Numerous granitic pegmatites are widespread throughout the Moldanubian Zone. The following groups were distinguished (modified from Novák 2005 and Novák and Cempírek 2010). 


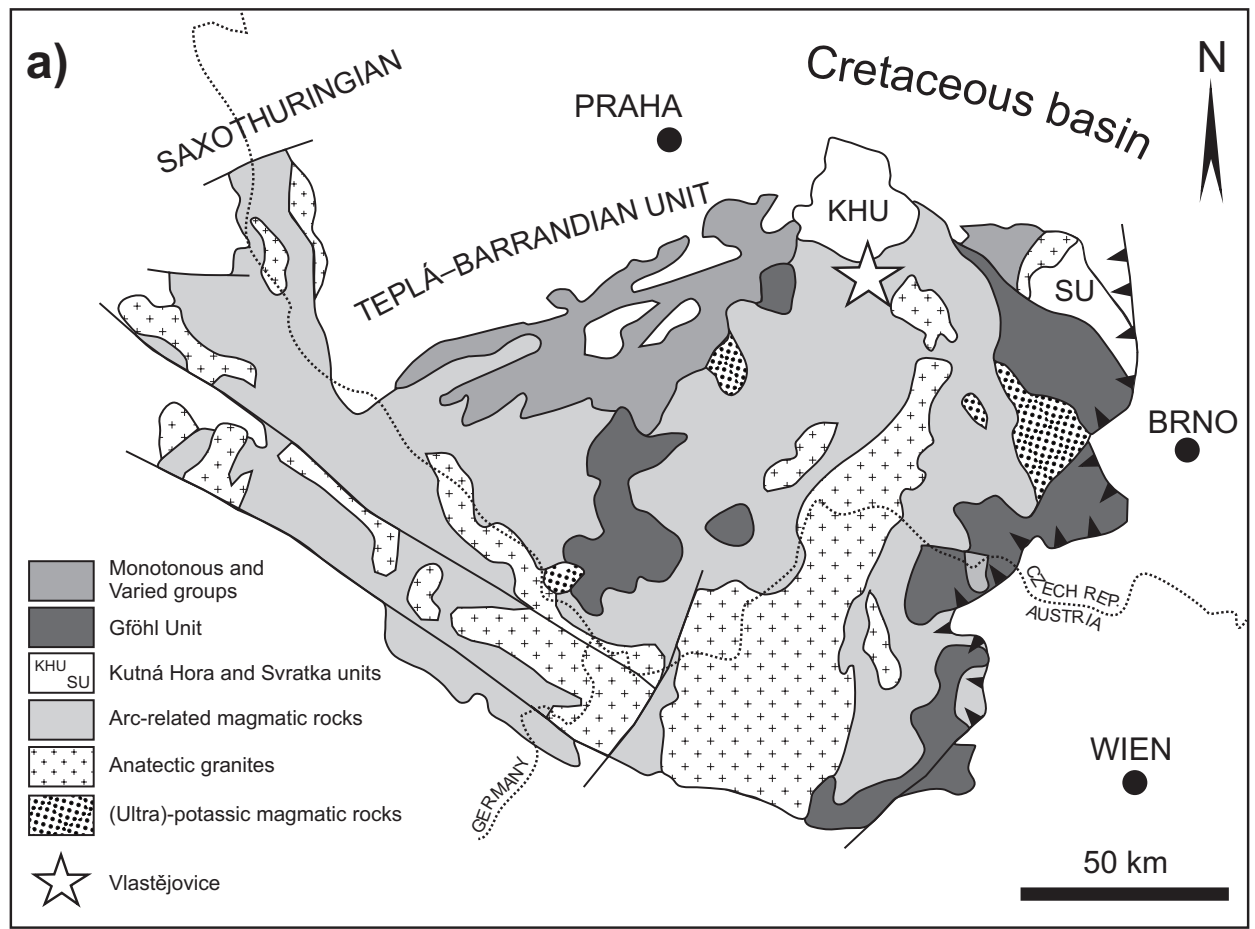

Fig. 1 Geological sketch maps of the Moldanubian Zone in the Bohemian Massif (a) and Vlastějovice region (b). B - Březina pegmatite, $\mathrm{N}$ - Nosatá skála pegmatite, $\mathrm{H}$ Holý vrch deposit, M - Magdalena deposit (modified from Koutek 1950).

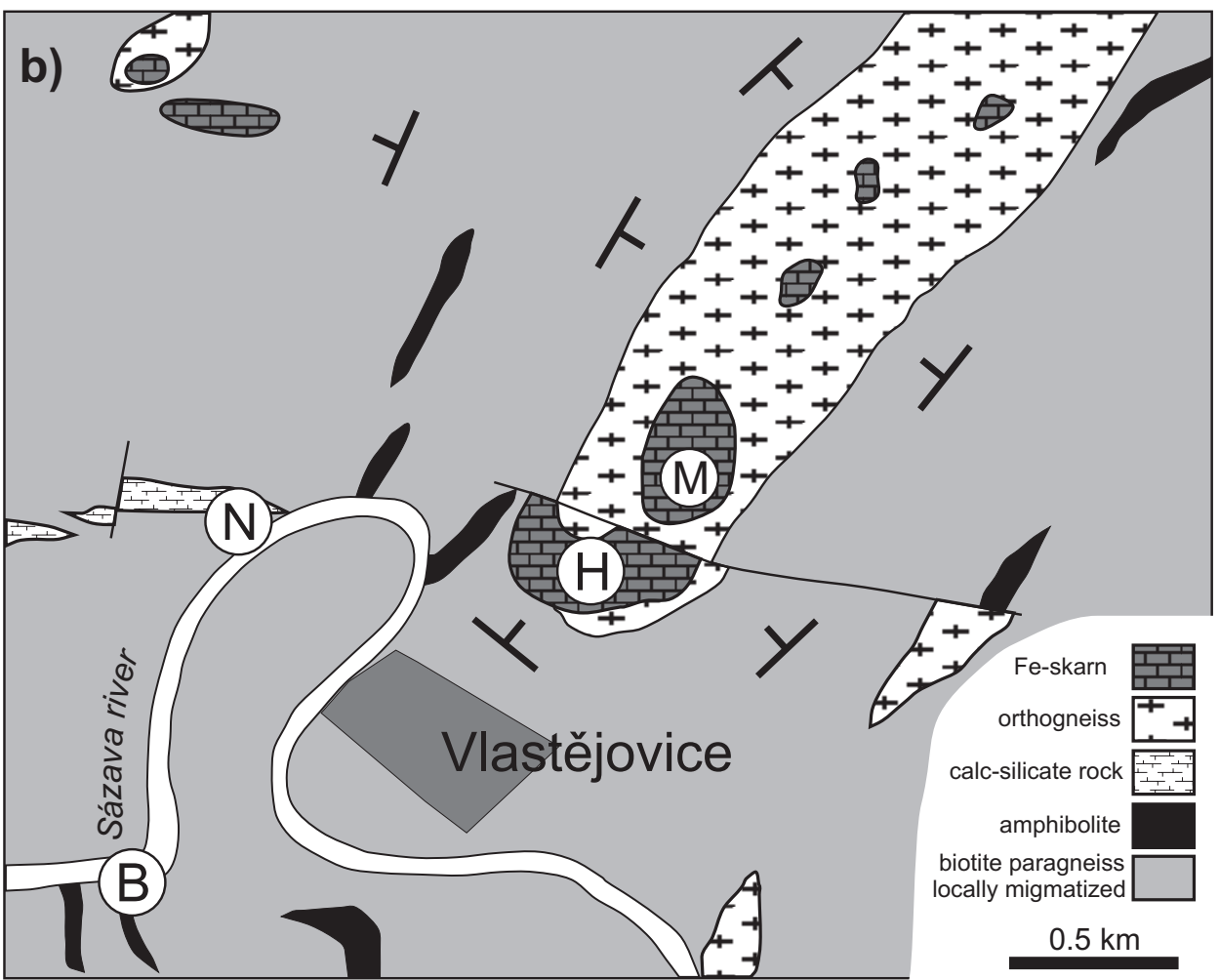

(i) Rare pre-Variscan (metamorphosed) pegmatites are represented by small, simply zoned, coarse-grained pegmatite-like nests (biotite + muscovite + oxy-schorloxy-dravite) in Ordovician orthogneisses (Vrána and Kröner 1995; Povondra and Vrána 1996; Breiter et al. 2005a). They are developed at some localities (e.g., Přibyslavice, Uhelná Př́bram, Bechyně, Křížová hora,
Vlastějovice); however, these pegmatites were only exceptionally studied (Novák 1981; Staněk and Schnorrer 1983; Povondra et al. 1987; Povondra 1989; Kadlec 2007a) and the age was not confirmed by radiometric dating. Furthermore, in the Prribyslavice orthogneiss some pegmatites are evidently post-tectonic and postmetamorphic (Povondra et al. 1987, 1998; Novák and 
Cempírek 2010; Bačík et al. 2013), and Variscan age of at least part of these pegmatites is very likely. Except for the Prribyslavice and Hamry nad Sázavou pegmatites they have not been examined in detail.

(ii) Anatectic pegmatites (abyssal class sensu Černý and Ercit 2005; anatectic pegmatites sensu London 2008), include several distinct pegmatite groups. a) Dumortierite-bearing dikes (dumortierite + schorl + olenite \pm foitite, garnet, kyanite) are enclosed in high-grade metamorphic rocks (Vrána et al. 2009) and occur almost exclusively along NE to E extremity of the Moldanubian Zone, mainly in the adjacent Kutná Hora Unit (Cempírek and Novák 2006; Cempírek et al. 2006; Vrána et al. 2009) and, less commonly, in the Gföhl Unit - Vémyslice near Moravský Krumlov (Cempírek and Novák 2004). b) Borosilicate-bearing pegmatite veinlet (grandidierite-ominelite + boralsilite + werdingite + dumortierite + schorl) cuts leucogranulite of the Bory Granulite Massif, which post-dated the development of foliation in the host granulite at $\mathrm{T} \sim 750{ }^{\circ} \mathrm{C}$ and $\mathrm{P} \sim 0.6-0.8 \mathrm{GPa}$ (Cempírek et al. 2010). c) Coarse-grained, cordierite-rich leucosomes (cordierite + biotite + schorl-dravite \pm dumortierite) occur in migmatized gneisses of the Bory Granulite Massif and locally show pegmatitic textures (Povondra et al. 1992). d) Simply zoned, common (likely anatectic) pegmatites with accessory andalusite and cordierite are abundant mainly in the Strážek Moldanubicum, which mostly show transitional (diffuse) contacts to their country rocks (migmatized gneisses and granulites) and locally contain large crystals of smoky quartz, feldspars, muscovite and tourmaline (schorl, oxy-schorl, dravite, foitite, magnesio-foitite) typically developed in pockets (Gadas et al. 2012; Novák et al. 2004; Povondra 1981). e) Common pegmatites (sensu London 2008) are enclosed in a variety of rocks; anatectic origin is very likely. Where the host rocks have contrasting chemical composition, the pegmatites may have undergone a variable degree of in situ contamination (e.g., diopside pegmatites from pyroxene gneisses and marbles, scapolite pegmatites in marbles, amphibole-allanite pegmatites from Fe-skarns; Novák 2005). Most anatectic pegmatites are spatially related to the Gföhl Unit.

(iii) Pegmatites of rare-element class are the most abundant and exhibit high variability in shape, size, textures, degree of fractionation and mineralogy. They are simple barren to highly fractionated with LCT, NYF and/ or MIXED geochemical signature (see Černý and Ercit 2005; Černý et al. 2012). The rare-element granitic pegmatites of the Moldanubian Zone could be sub-divided into four groups $(\mathrm{a}-\mathrm{d})$ according to their geochemical affinity (family) and $\mathrm{P}-\mathrm{T}$ conditions.

a) Pegmatites of the LCT family are typically enriched in B with tourmaline (schorl, oxy-schorl, dravite, foitite, fluor-elbaite, elbaite, fluor-liddicoatite, rossmanite, darrellhenryite; e.g., Povondra et al. 1985; Novák and Povondra 1995; Selway et al. 1998, 1999; Novák et al. 1999a, 2012, in print; Novák and Taylor 2000) as an omnipresent accessory to minor mineral. Less evolved common pegmatites are characterized by the presence of dravite, oxy-dravite, oxy-schorl to schorl (Novák et al. 2004), locally andalusite, cordierite and garnet. More fractionated beryl-type pegmatites, locally with some accessory minerals (oxy-schorl, schorl, dravite, oxy-dravite, beryl, fluorapatite, niobian rutile, ilmenite, monazite$(\mathrm{Ce})$, xenotime-(Y), zircon, cordierite, garnet, columbitetantalite, Y,REE-oxide minerals; e.g., Povondra 1981; Černý et al. 1997, 2000, 2007; Novák et al. 2004, 2008; Breiter et al. 2005b; Škoda et al. 2011), are less abundant than the more evolved complex pegmatites (Li-bearing; Li-micas $>$ Li-tourmalines $>$ amblygonite $>$ petalite; Povondra et al. 1985; Němec 1989, 1990; Černý et al. 1995, 2003; Teertstra et al. 1995; Novák et al. 1999b, 2013), some with variety of accessory minerals (see Novák and Cempírek 2010 and references therein). Their mineral assemblages with common andalusite, sekaninaite and petalite suggest an emplacement and crystallization at $\mathrm{P}<\sim 0.2-0.3 \mathrm{GPa}$. Nevertheless, based on fluid-inclusions study, Ackerman et al. (2007) suggested $\mathrm{P}=0.31-0.43$ GPa for the elbaite-subtype pegmatite from Vlastějovice. Parental granites of the rare-element (LCT) pegmatites are not known; nevertheless, tourmaline-bearing leucogranites (e.g., Buriánek and Novák 2004, 2007) closely associated with durbachites were proposed as probable source.

b) Some mostly "stockscheider-type" marginal pegmatites (LCT family), locally with beryl and Be-phosphates, are related to Eisgarn granite and chiefly to highly evolved granites of the Moldanubian Batholith near Lásenice and Horní Stropnice (e.g, Kostelní Vydří, Homolka, Šejby; Breiter and Scharbert 1995; Cempírek et al. 1999; Pavlíček et al. 2009).

c) Intragranitic pegmatites of NYF family (Škoda et al. 2006; Škoda and Novák 2007; Novák and Filip 2010; Novák et al. 2011, 2012) occur exclusively in the Třebíč Pluton, western Moravia, and in the Čertovo břemeno (Milevsko) Pluton, southern Bohemia. Both plutons form large syn-exhumation tabular bodies (Dobeš and Pokorný 1988; Žák et al. 2005) interpreted as a product of mixing between enriched mantle-derived magma and a crustal melt (Holub 1997; Janoušek et al. 2000; Janoušek and Holub 2007). Typical minor to accessory minerals of pegmatites include common phlogopite, allanite-(Ce), tourmaline (dravite, schorl, fluor-schorl; Novák et al. 2011), aeschynite- and euxenite-group minerals, titanite, ilmenite, actinolite, and rare beryl. Recently, thin pegmatite dikes with analogous mineral assemblages were found in the Tábor Pluton (Dražičky SW of Tábor). 
d) Merely the Li-bearing pegmatite from Kracovice near Třebić is considered to belong to the MIXED family (Novák et al. 2012). It contains, along with Li-bearing minerals (Li-micas, Li-tourmalines), also common topaz, Y-bearing spessartine and Y,REE-oxide minerals (fergusonite, samarskite, pyrochlore). Also Drahonín III and IV pegmatites near Strážek with tourmaline, sekaninaite, beryl, Y-rich spessartine and Y,REE-oxide minerals (Škoda and Novák 2004) may belong to the MIXED family.

Rare-element (LCT) granitic pegmatites from Bavarian Moldanubicum (e.g., Hagendorf, Zwiesel, Pleystein; e.g., Mücke et al. 1990; Dill et al. 2012 and references therein) with abundant primary $\mathrm{Fe}, \mathrm{Mn}$-phosphates but rare tourmaline are very likely related to the granites dated at 326-321 Ma (Siebel 1995; Chen and Siebel 2004; Gerdes et al. 2003; Finger et al. 2007 and references therein). However, there are no analogical occurrences known from the territory of Czech Republic. Also rare granitic pegmatites in the Austrian part of the Moldanubian Zone, where Li-bearing pegmatites with Li-tourmalines and scarce Li-micas were found (Ertl et al. 2004, 2005, 2012), are not discussed.

(iv) Pegmatites of miarolitic class are very rare and only some intragranitic NYF pegmatites enclosed in the Čertovo břemeno Pluton, central Bohemia (Kovářov, Vepice; Škoda et al. 2004) and from the Třebíč Pluton (Velké Meziřričí, Novák and Cempírek 2010; A. Zachař pers. comm. 2012) closely spatially and mineralogically related to the above NYF pegmatites of rare-element class show typical features of miarolitic pegmatites large pockets with crystals of smoky quartz, feldspars and titanite, and close relationship to the parental granite. Small miarolitic (LCT) pegmatites exceptionally occur also in anatectic granites (Eisgarn) of the Central Moldanubian Pluton (Telč region).

\subsubsection{Geochronology}

The radiometric ages ( $\mathrm{U}-\mathrm{Pb}$ monazite, $\mathrm{U}-\mathrm{Pb}$ columbite) of the individual pegmatite groups were only scarcely published. (i) We do not have any data from metamorphosed pegmatites; however, they are expected to be Ordovician as their parental orthogneisses are (Vrána and Kröner 1995). (ii) The age of anatectic pegmatites is also uncertain. Their relations to the MP-HT regional metamorphism and anatexis, and the absence of evident metamorphic overprint, suggest that they are mostly Variscan but some might be older. (iiia) The pegmatites of the rare-element class (LCT) crystallized in a short period of 340-332 Ma (Novák et al. 1998; Ertl et al. 2004; Melleton et al. 2012), although new data also indicate the age of emplacement of some Li-bearing pegmatites at $\sim 325 \mathrm{Ma}$ (Melleton et al. 2012). (iiib) The pegmatites related to the Moldanubian Batholith including their miarolitic relatives were younger; they have been dated at $\sim 320 \mathrm{Ma}$ (whole rock Rb-Sr; "stockscheider-type"; Breiter and Scharbert 1998) and 331-326 Ma (the Eisgarn and Weinsberg suites), respectively. (iiic) The intragranitic NYF pegmatites of the Třebíč, Čertovo břemeno and Tábor plutons as well as their miarolitic relatives (iv) were not dated radiometrically but the ages of their parental granites of $\sim 340-335 \mathrm{Ma}$ (Holub et al. 1997b; Janoušek and Gerdes 2003; Kotková et al. 2010; Kusiak et al. 2010) suggest the formation in the same period as the LCT pegmatites given above and support orogenic origin of these NYF pegmatites (Černý et al. 2012; Novák et al. 2012).

\subsection{Geological setting of the Vlastějovice region}

The Vlastějovice locality is situated in the Ledeč-Chýnov belt of the Varied Group (Drosendorf Unit), Moldanubian Zone, along the border with the Kutná Hora Unit (Fig. 1a). Dominant two-mica paragneisses to locally migmatized biotite-sillimanite paragneisses contain common intercalations of amphibolite, pyroxene gneiss, quartzite, marbles, biotite to two-mica tourmaline-bearing orthogneisses and rare eclogite (Breiter et al. 2005a), which are spatially associated with large bodies of Fe-skarn. The regional metamorphic foliation trends NE-SW and dips at moderate to steep angles to the NW. Several lenticular bodies of Fe-skarns, up to several tens of meter thick and several hundreds of meter long, occur in the NE-SW trending synclinal structure at Vlastějovice building the Holý vrch and Magdalena Fe-skarn magnetite deposits (Fig. 1b; Koutek 1950; Potužák 1996). The contacts of the Fe-skarn are generally parallel to the foliation of the host gneisses. Small bodies of leucocratic granites and simple tourmaline-bearing pegmatites are common in this region as well (Kadlec 2009).

Biotite to two-mica orthogneisses form a NE-SW elongated body, $3.5-0.5 \mathrm{~km}$ in diameter, located $\mathrm{N}$ of Vlastějovice (Fig. 1b). This body is a member of a discontinuous belt of orthogneisses (Klečka et al. 1992; Breiter et al. 2005a) including the Přibyslavice orthogneiss. The Vlastějovice orthogneiss is a medium-grained rock with moderate foliation and mostly tectonic contacts with the adjacent Fe-skarn. The contact was modified locally by intrusion of a footwall granite-pegmatite. Chemical composition of the orthogneiss is given in Tab. 1. Orthogneiss body contains several simple pegmatites with minor to accessory biotite, muscovite, and tourmaline.

The Fe-skarn bodies in Vlastějovice are highly heterogeneous, consisting of grossular-andradite $>$ hedenbergite $>$ diopside $>$ magnetite $>$ epidote. Minor to 
Tab. 1 Chemical compositions of rocks from Vlastějovice (wt. \%)

\begin{tabular}{|c|c|c|c|c|c|c|c|}
\hline & 1 & 2 & 3 & 4 & 5 & 6 & 7 \\
\hline & FGM29 & V8 & FGM28 & V13 & VLS-1 & VLS-2 & VLS-3 \\
\hline $\mathrm{SiO}_{2}$ & 74.34 & 71.19 & 73.55 & 43.26 & 40.77 & 40.11 & 41.79 \\
\hline $\mathrm{TiO}_{2}$ & 0.02 & 0.16 & 0.17 & 0.82 & 0.44 & 0.59 & 0.27 \\
\hline $\mathrm{Al}_{2} \mathrm{O}_{3}$ & 15.51 & 13.30 & 16.18 & 12.36 & 9.94 & 10.24 & 1.51 \\
\hline $\mathrm{Fe}_{2} \mathrm{O}_{3}$ & 0.34 & 0.13 & 1.46 & 4.74 & 20.69 & 13.89 & 19.11 \\
\hline $\mathrm{FeO}$ & - & 1.75 & - & 11.76 & - & - & - \\
\hline $\mathrm{MnO}$ & 0.01 & 0.03 & 0.03 & 0.40 & 0.79 & 0.51 & 0.35 \\
\hline $\mathrm{MgO}$ & 0.01 & 0.37 & 0.24 & 2.00 & 2.17 & 2.60 & 5.21 \\
\hline $\mathrm{CaO}$ & 0.88 & 1.30 & 0.96 & 14.48 & 24.04 & 31.01 & 29.97 \\
\hline $\mathrm{Na}_{2} \mathrm{O}$ & 4.90 & 1.17 & 3.12 & 2.46 & 0.34 & 0.19 & 0.09 \\
\hline $\mathrm{K}_{2} \mathrm{O}$ & 3.80 & 8.34 & 5.45 & 2.71 & 0.02 & 0.03 & 0.01 \\
\hline $\mathrm{P}_{2} \mathrm{O}_{5}$ & 0.00 & 0.28 & 0.23 & 0.23 & 0.14 & 0.14 & 0.20 \\
\hline $\mathrm{H}_{2} \mathrm{O}$ & - & 0.47 & - & 0.94 & - & - & - \\
\hline LOI & - & 1.18 & - & 2.96 & 0.50 & 0.60 & 1.14 \\
\hline Sum & 99.81 & 99.67 & 101.39 & 99.12 & 99.84 & 99.91 & 99.65 \\
\hline
\end{tabular}

1 - orthogneiss, 2 - orthogneiss (Syka 1990), 3 - Footwall granite-pegmatite (granite I), 4 - amphibole-rich pegmatite (Syka 1990), 5, 6, 7 - Fe-skarn

accessory minerals include amphibole, biotite, calcite, quartz, allanite-(Ce), plagioclase, K-feldspar, scapolite, hematite, titanite, apatite, and fluorite. The following rock types were distinguished: (i) very abundant skarn s.s.: monomineralic massive garnetite and banded garnet-clinopyroxene rock commonly forming central parts of the Fe-skarn bodies; (ii) minor clinopyroxene-garnet-epidote rock; (iii) lenses of massive magnetite, up to several $\mathrm{m}$ in diameter; (iv) hybrid rock (hastingsite + almandine + biotite + quartz $+\mathrm{K}$-feldspar + plagioclase $)$ forming a zone, a few decimeters to several meters thick, located between the Fe-skarn and the surrounding orthogneisses. The chemical analyses of various types of Fe-skarns are given in Tab. 1. The Fe-skarns were regionally metamorphosed at $\mathrm{T} \sim 590-680{ }^{\circ} \mathrm{C}$ and $\mathrm{P}$ $\sim 0.45-0.65 \mathrm{GPa}$, corresponding to the (ii) MP-HT Variscan metamorphic event (Žáček 1997). Several types of hydrothermal mineralization cutting the Fe-skarn form veins and pods, up to several dm thick: calcite + apophyllite, quartz + prehnite + apophyllite, datolite + prehnite, fluorite + calcite (Tvrdý 2000; Žáček and Fišera 2001; Kadlec 2007b, 2012). Rare quartz-calcite veins with antimony mineralization (dominant berthierite) are mostly bound to steep $\mathrm{S}-\mathrm{N}$ trending mylonite zones (Koutek and Žák 1953; Brabec 2002).

\section{Experimental methods}

\subsection{Electron microprobe}

Tourmaline, garnet, amphibole, micas, plagioclase and some associated minerals were analyzed by an electron microprobe Cameca SX 100 at the Joint Laboratory of
Electron Microscopy and Microanalysis, Department of Geological Sciences, Masaryk University, Brno and the Czech Geological Survey, Brno in a wavelengthdispersive mode and with accelerating voltage of 15 $\mathrm{kV}$, beam current of 10-20 nA and spot size of 1-5 $\mu \mathrm{m}$. The following X-ray lines and standards were used: $K_{\alpha}$ : sanidine $(\mathrm{Si}, \mathrm{Al}, \mathrm{K})$, albite $(\mathrm{Na})$, olivine $(\mathrm{Mg})$, andradite $(\mathrm{Ca}, \mathrm{Fe})$, rhodonite $(\mathrm{Mn})$, hornblende $(\mathrm{Ti})$, chromite $(\mathrm{Cr})$, topaz $(\mathrm{F}), \mathrm{ZnS}(\mathrm{Zn}), \mathrm{NaCl}(\mathrm{Cl})$, apatite (P) and $\mathrm{Ni}(\mathrm{Ni}) ; L_{\alpha}$ : YAG $(\mathrm{Y})$ and $L_{\beta}$ : benitoite $(\mathrm{Ba})$. The raw data were reduced using PAP matrix corrections (Pouchou and Pichoir 1985). The crystal-chemical formulae of tourmaline were calculated based on the general formula $X Y_{3} Z_{6} T_{6} O_{18}\left(B O_{3}\right)_{3} V_{3} W$, where $X=\mathrm{Na}$, $\mathrm{Ca}, \mathrm{K}$, vacancy; $Y=\mathrm{Fe}, \mathrm{Mg}, \mathrm{Mn}, \mathrm{Ti}, \mathrm{Al}, \mathrm{Li} ; Z=\mathrm{Al}$, $\mathrm{Fe}, \mathrm{Mg}, \mathrm{Cr} ; \mathrm{T}=\mathrm{Si}, \mathrm{Al}, \mathrm{B} ; B=\mathrm{B} ; V=\mathrm{OH}, \mathrm{O} ; W=\mathrm{OH}$, F,O (see Henry et al. 2011). The $Z$-site was considered to be occupied by $\mathrm{Al}$ and $\mathrm{Mg}, \mathrm{Fe}_{\text {tot }}$ as $\mathrm{FeO}$. Normalization to $\mathrm{Si}=6$ apfu was chosen because of the absence of $\mathrm{Fe}^{2+} / \mathrm{Fe}^{3+}$ measurements in black tourmaline and elevated contents of $\mathrm{Li}$ in tourmalines from the Elbaite pegmatite (Povondra et al. 1985). The crystal-chemical formulae of garnet were calculated from EMPA data and normalized to 8 cations and 12 oxygens whereby Fe was split to $\mathrm{Fe}^{3+}$ or $\mathrm{Fe}^{2+}$ according to the stoichiometry. The crystal-chemical formulae of amphibole and biotite were obtained based on 24 anions or 12 anions $(\mathrm{O}, \mathrm{OH}, \mathrm{F})$ respectively, assuming that all $\mathrm{Fe}$ is divalent in both cases. The crystal-chemical formulae of feldspars were calculated based on 8 oxygens. Calculations of $\mathrm{Mg} /(\mathrm{Mg}+\mathrm{Fe})$ values in tourmaline, amphibole and mica were done using total $\mathrm{Fe}$ as $\mathrm{FeO}_{\text {tot }}$, disregarding its potential valence and distinct position in the crystal structure of minerals. All mineral abbreviations in 
tables, figures and in the text were taken from Whitney and Evans (2010).

\subsection{Whole-rock geochemistry}

The bulk compositions of Fe-skarn were determined at the Acme Chemical Laboratories Ltd., Vancouver, Canada, by using ICP-ES after they were melted with lithium borate. Trace elements were analyzed by ICP-MS following a lithium tetraborate fusion. See $h t t p: / / w w w$. acmelab.com for further details.

\section{Geological setting, internal structure and mineral assemblages of the Vlastějovice granitic pegmatites}

Granitic pegmatites from the region were divided into three distinct groups based on their likely parental magmatic rock, internal structure, shape and size of bodies, mineral assemblages and degree of host-rock contamination (Kadlec 2007a, 2009; Novák and Cempírek 2010).

\subsection{Tourmaline-bearing pegmatites from orthogneiss}

Several elongated pods, up to $\sim 0.5-1.5 \mathrm{~m}$ long and up to $0.5 \mathrm{~m}$ thick, were found in the Holý vrch quarry. Pegmatite pods show transitional contacts and their elongation is often concordant with the foliation of the host orthogneiss (Fig. 2). However, this foliation does not continue into the coarse-grained pegmatite. Fragmentation of elongated tourmaline crystals and their healing is common. The pegmatites $(\mathrm{Qz}+\mathrm{Kfs}+\mathrm{Pl})$ are simply zoned showing increasing grain size from the contact inwards and locally small quartz core. Biotite, abundant in outer parts of pegmatite pods, mostly predominates over prismatic crystals of black tourmaline (dravite, schorl), up to $10 \mathrm{~cm}$ long, more common in the center. Large flakes of muscovite and small grains of green fluorapatite are frequent but other accessory minerals, such as zircon, are rare (Kadlec 2007a). Staněk and Schnorrer (1983) described also phenakite and buergerite from this type of pegmatite; however,

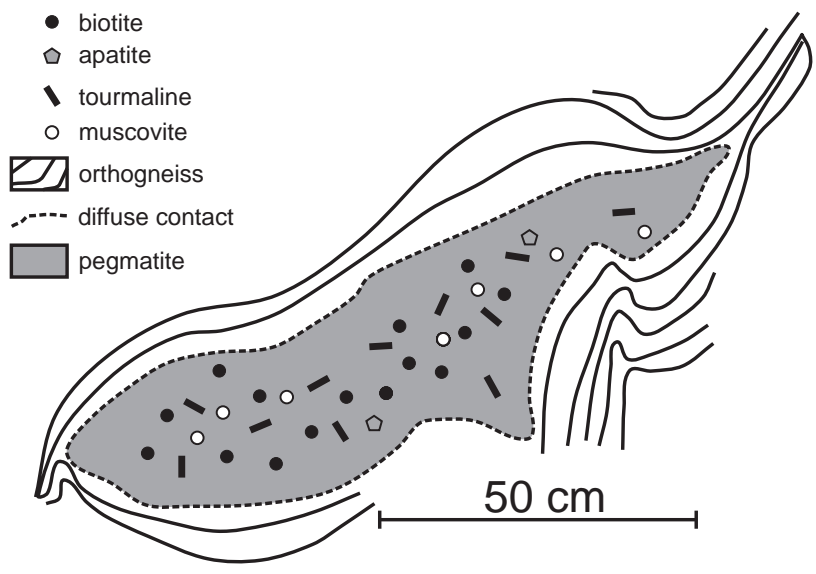

Fig. 2 Idealized cross section through pegmatite in orthogneiss (modified from Kadlec 2007a).

determination of buergerite is not unequivocal and its presence seems very unlikely.

\subsection{Amphibole-bearing pegmatites}

Contaminated, amphibole-bearing pegmatites (barren pegmatites according to Ackerman et al. 2007) are very common and about 100 dikes were mentioned by Vavř́n (1960, 1962), Ackerman et al. (2007), Kadlec (2007a, 2009) and Novák and Cempírek (2010). They are randomly distributed within the whole Fe-skarn body (Fig. $3 a-b)$, although we have never found them in the hybrid rock. Based on major and minor minerals (Tab. 2), degree of hydrothermal overprint and presence or absence of pockets, four major subtypes were recognized, as follows.

(i) Ordinary amphibole-bearing pegmatites (Pl + Qz + Kfs + Amp) are by far the most abundant but also quite variable in size, shape, thickness of reaction rims and proportion of the individual minerals (Vavř́n 1962; Novák and Hyršl 1992; Žáček et al. 2003). They form elongated dikes to irregular intrusive bodies (Figs $3 \mathrm{~b}, 4)$ commonly several $\mathrm{dm}$ thick and several $\mathrm{m}$ long (Fig. $3 \mathrm{~b}-\mathrm{d}$ ); the largest dike was $\sim 1.5 \mathrm{~m}$ thick. They cut exclusively the Fe-skarn with irregularly developed reaction zones (Fig. 4). Abundant reaction rims, up to $30 \mathrm{~cm}$ thick, consist of dominant amphibole and locally also fluorite, biotite and a relatively $\mathrm{Ca}$-rich plagioclase $\left(\mathrm{An}_{06-35}\right)$ compared to that from the central portions of

Tab. 2 Mineral assemblages of amphibole-bearing pegmatites

\begin{tabular}{llll}
\hline Pegmatite subtype & \multicolumn{1}{c}{ Major minerals } & \multicolumn{1}{c}{ Minor minerals } & Accessory minerals \\
\hline ordinary pegmatites & $\mathrm{Pl}>\mathrm{Qz}, \mathrm{Kfs}, \mathrm{Amp}$ & $\mathrm{Fl}, \mathrm{Aln}, \mathrm{Bt}, \mathrm{Hd}, \mathrm{Grt}$ & $\mathrm{Ttn}, \mathrm{Cal}, \mathrm{Mag}, \mathrm{Ax}, \mathrm{Py}, \mathrm{Po}, \mathrm{Wo}$ \\
fluorite-rich pegmatites & $\mathrm{Pl}>\mathrm{Fl}>\mathrm{Kfs}, \mathrm{Qz}, \mathrm{Amp}$ & $\mathrm{Bt}, \mathrm{Aln}$ & $\mathrm{Ttn}, \mathrm{Mag}$ \\
pegmatites with hydrothermal overprint & $\mathrm{Pl}>\mathrm{Kfs}, \mathrm{Qz}, \mathrm{Fl}$ & $\mathrm{Amp}, \mathrm{Prh}, \mathrm{Apo}, \mathrm{Ep}, \mathrm{Bt}$ & $\mathrm{Ttn}, \mathrm{Aln}, \mathrm{Grt}, \mathrm{Cal}$, Tur, Opl \\
pocket pegmatite & $\mathrm{Pl}>\mathrm{Kfs}, \mathrm{Qz}, \mathrm{Ab}, \mathrm{Pl}$ & $\mathrm{Fl}, \mathrm{Bt}, \mathrm{Amp}$ & Aln, Cal, Apo, phenakite \\
\hline
\end{tabular}

Products of hydrothermal alteration of allanite-(Ce) in most dikes disregarding the subtype include: bastnäsite-(Ce) $>>$ thorogummite, ancylite, brockite, parisite-(Ce), rhabdophane-(Ce) (Goliáš 2002); further accessory minerals in amphibole-bearing pegmatites: celadonite, fluorapatite, uraninite, thorite, pyrochlore-supergroup mineral, bismuth, bismuthinite (e.g., Rezek and Krist 1985; Goliáš 2002). 

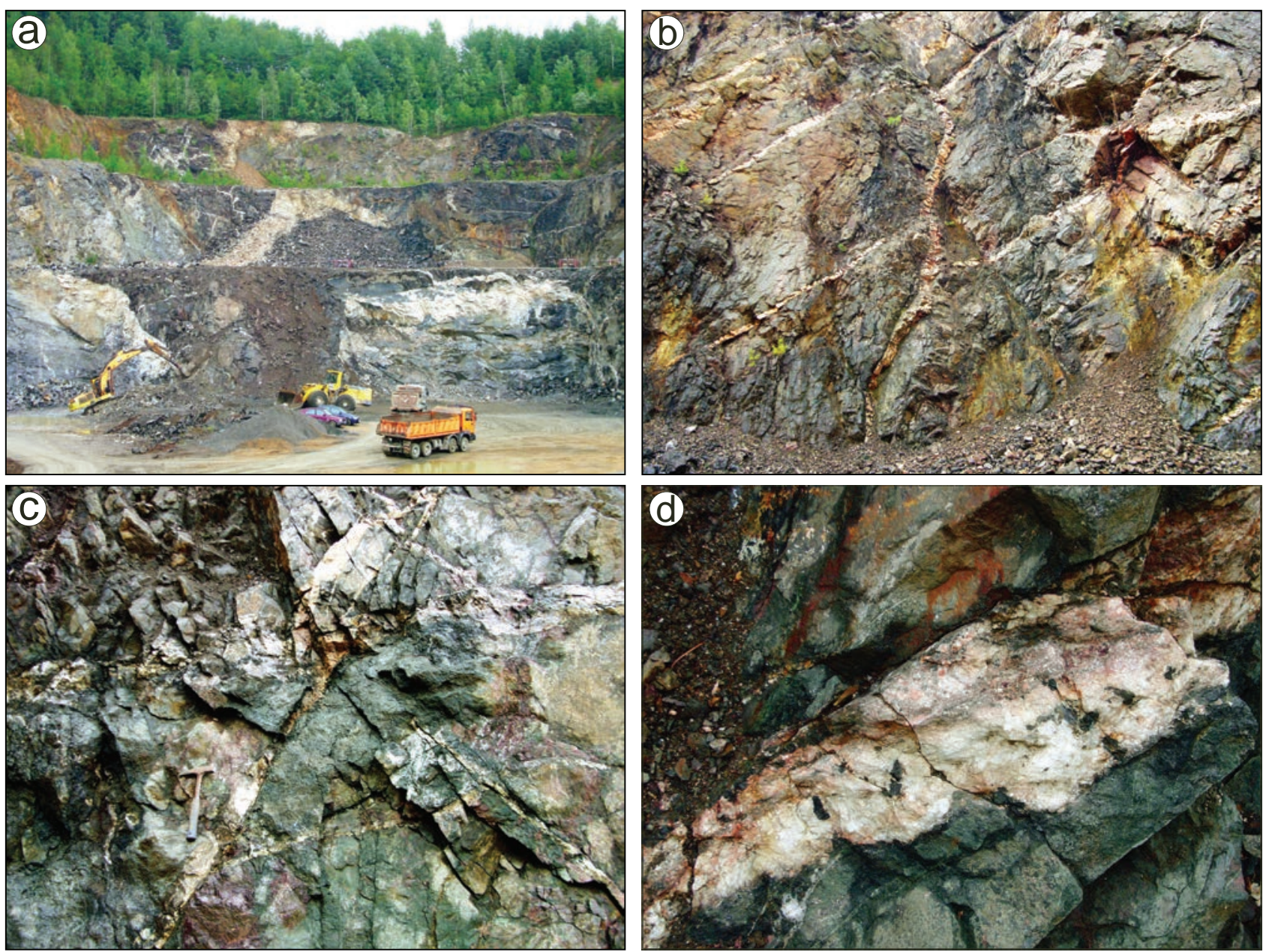

Fig. 3 Amphibole-bearing pegmatites in Fe-skarn: a - view on the Holý vrch quarry, Vlastějovice, note Pegmatite No. 12 in the upper left part of the quarry, several outcrops of Footwall granite-pegmatite (light areas), and amphibole-bearing pegmatites in the upper right part of the quarry; b - amphibole-bearing pegmatite dikes cutting the Fe-skarn; c - crossing of amphibole-bearing (subhorizontal) and tourmaline-bearing pegmatite (subvertical); d - detail of amphibole-bearing pegmatite dike $\sim 25 \mathrm{~cm}$ thick. Field situation on 31 August 2010 (a) and on $28 \mathrm{March} 2009$ (b to d); photo M. Novák.

pegmatite $\left(\mathrm{An}_{00-20} ;\right.$ Ackerman et al. 2007). The pegmatites are coarse-grained, commonly with subhomogeneous internal structure (Fig. 3d), and contain locally abundant amphibole $>$ fluorite $>$ biotite $>>$ hedenbergite $>$ andradite-grossular $\sim$ allanite $\sim$ epidote $\sim$ titanite $\sim$ calcite $\sim$ magnetite (the most common order) along with dominant plagioclase, quartz and locally also abundant K-feldspar (Tab. 2). Very rare axinite-(Fe) and tourmaline were also identified. Monomineralic grey quartz forms locally irregular masses and veins located often along the contact with the host skarn, enclosing its fragments. Black to green-black amphibole (hastingsite to ferro-edenite) is present as euhedral to subhedral phenocrysts, up to $\sim 10 \mathrm{~cm}$ in size, and massive, coarse-grained aggregates (Žáček and Povondra 1991; Žáček 2007). Common allanite-(Ce) present in amphibole-bearing pegmatites and scarcely in host Fe-skarn is often replaced by secondary fluorcarbonates (e.g., bastnäsite; Tab. 2), particularly if associated with fluorite (Goliáš 2002). Subhedral to euhedral crystals of yellowish-brown Al-rich titanite, less than $1 \mathrm{~cm}$ across, occur in black hastingsite and fluorite, chiefly from reaction zones between pegmatite and skarn (Mrázek and Vrána 1985). Abundant to scarce, dark violet, purple to rarely colorless fluorite forms coarse-grained aggregates, up to several $\mathrm{dm}$ in size, in the pegmatite or in the exocontact zone. Fluorite locally predominates over quartz and feldspars. It is closely associated with allanite with deep violet to black rims around allanite grains. Ackerman (2005), based on the REE-geochemistry and fluid inclusion study, suggested that the fluorite crystallized during the magmatic-hydrothermal transition. Also wollastonite, chlorite, and pyrite occur in minor amounts mostly in marginal parts of the pegmatite dikes (e.g., Vavř́n 1960, 1962; Žáček and Povondra 1991; Novák and Hyršl 1992; Žáček et al. 2003; Houzar et al. 2009). 
(ii) Fluorite-rich, amphibole-bearing pegmatite dikes are relatively common only in the Magdalena Feskarn body. They form thin (up to $30 \mathrm{~cm}$ thick) elongated, vertical and locally asymmetric dikes, where fluorite is concentrated to the upper zone adjacent to contact. Reaction rims are negligible. Biotite is more abundant than in the ordinary amphibole-bearing pegmatites (Tab. 2).

(iii) Amphibole-bearing pegmatites with significant hydrothermal overprint and small pockets are very similar to the ordinary amphibole-bearing pegmatites in internal structure and primary mineral assemblages except for almost total absence of biotite in this pegmatite type. Hydrothermal minerals prehnite and apophyllite are typically present in small pockets enclosed in K-feldspar associated with fluorite. Minor calcite, garnet, titanite, allanite, epidote, opal, and very rare fibrous tourmaline, pyrite, and bastnäsite were also identified in this assemblage (Tab. 2). Several pegmatite dikes occur exclusively in the upper part of the Magdalena Fe-skarn body.

(iv) Amphibole-bearing pegmatite with a large pocket $\left(\sim 1 \mathrm{~m}^{3}\right)$ was described by Vavř́n (1960), Čujan (1966) and Kadlec (2010) from the Magdalena Fe-skarn quarry. The zoned dike, $\sim 2 \mathrm{~m}$ thick, consists of outer oligoclase-rich unit and blocky K-feldspar with quartz in the core. The mineral assemblages also include amphibole, fluorite, biotite, and rare allanite. In the pocket, crystals of smoky quartz (up to $60 \mathrm{~cm}$ long), orthoclase, albite, calcite, apophyllite, phenakite, and clay minerals were identified (Kadlec 2010).

Crosscutting dikes of ordinary amphibole-bearing and tourmaline-bearing pegmatites described below have been found only recently (Fig. 3c), and show unambiguously that the former crystallized earlier than the latter (see also Čech 1985; Novák 2005; Ackerman et al. 2007; Novák and Cempírek 2010). The P-T conditions of the formation of amphibole-bearing pegmatites $\left(600-640^{\circ} \mathrm{C}\right.$ and $0.42-0.58 \mathrm{GPa}$ ) deduced from fluid inclusions (Ackerman et al. 2007) fall into the field of regional MP-HT metamorphism of the host rocks (Žáček 1997). Chemical compositions of amphibole-rich and quartz-poor ordinary amphibole-bearing pegmatites are given in Tab. 1.

\subsection{Tourmaline-bearing pegmatites}

\subsubsection{Occurrences}

Tourmaline-bearing pegmatites are rather common in Vlastějovice; 20 dikes were recognized including Libearing elbaite-subtype pegmatite studied by Čech (1985) and Ackerman et al. (2007). They are concentrated in a $\mathrm{W}-\mathrm{E}$ trending belt exclusively in the central and eastern part of the Holý vrch quarry; they are not known from the Magdalena Fe-skarn deposit. The pegmatites are

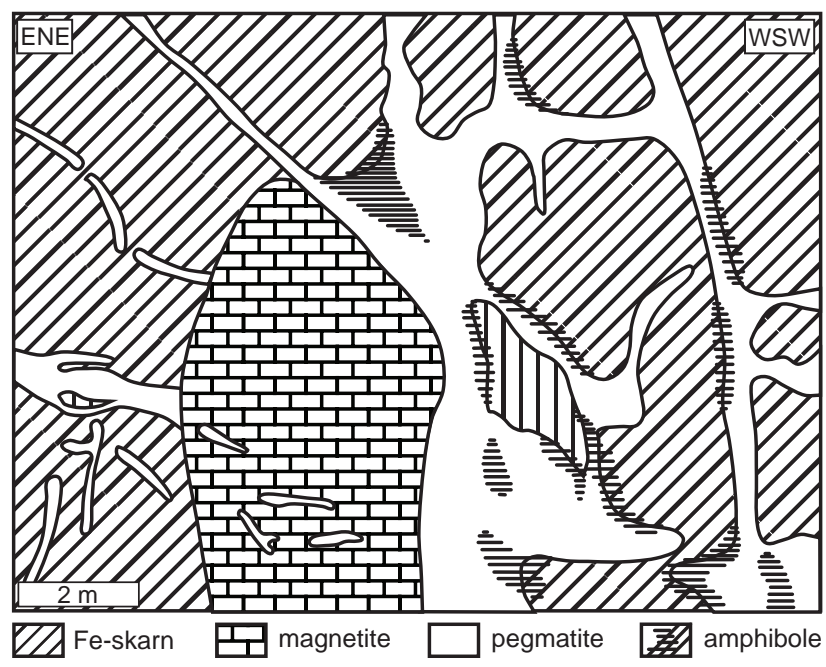

Fig. 4 Amphibole-bearing pegmatites cutting Fe-skarn (slightly modified from Novák and Hyršl 1992).

evidently related to the granite-pegmatite body in the footwall contact of the Fe-skarn (Figs 3a-5). In contrast to the amphibole-bearing pegmatites from the Fe-skarn, the tourmaline-bearing pegmatites were also found in paragneisses surrounding the Fe-skarn bodies (Kadlec 2007a, 2009). The pegmatites form NW-SE trending and steeply dipping dikes and rarely irregular bodies, with homogeneous to simply zoned internal structure (Kadlec 2007a, 2009; Novák and Cempírek 2010). Black to greyish black tourmaline forms solitary grains, coarse-grained aggregates and quite commonly graphic intergrowths of quartz + tourmaline, up to $10 \mathrm{~cm}$ in size. Six individual pegmatite bodies and Footwall granite-pegmatite were studied in detail. They represent typical examples of the tourmaline-bearing pegmatites characterized by distinct host rocks, degree of textural differentiation, geochemical fractionation and external contamination.

The Březina pegmatite forms a lenticular body, up to $3 \mathrm{~m}$ thick and $10 \mathrm{~m}$ long, located $\sim 2 \mathrm{~km} \mathrm{SW}$ of the Holý vrch Fe-skarn body. The pegmatite is heterogeneous, consisting of rather irregularly distributed patches of a dominant medium- to coarse-grained unit $(\mathrm{Qz}+\mathrm{Kfs}+\mathrm{Ab}$ $+\mathrm{Ms}+\mathrm{Bt}+\mathrm{Grt}+$ Tur), blocky K-feldspar and massive quartz (Tab. 3). The pegmatite is enclosed in migmatized biotite-sillimanite paragneiss with minor cordierite and is mostly concordant, only locally with discordant contacts to the foliated host rock.

The Nosatá skála pegmatite, a dike up to $\sim 5 \mathrm{~m}$ thick and several tens of $\mathrm{m}$ long, crops out $\sim 1 \mathrm{~km} \mathrm{~W}$ of the Holý vrch Fe-skarn body. The pegmatite shows heterogeneous internal structure consisting of irregularly distributed patches of a fine- to medium-grained unit within the prevalent coarse-grained pegmatite (both with an assemblage $\mathrm{Qz}+\mathrm{Kfs}+\mathrm{Ab}+\mathrm{Bt}+\mathrm{Ms}$; garnet and tourmaline are more common in the coarse-grained 


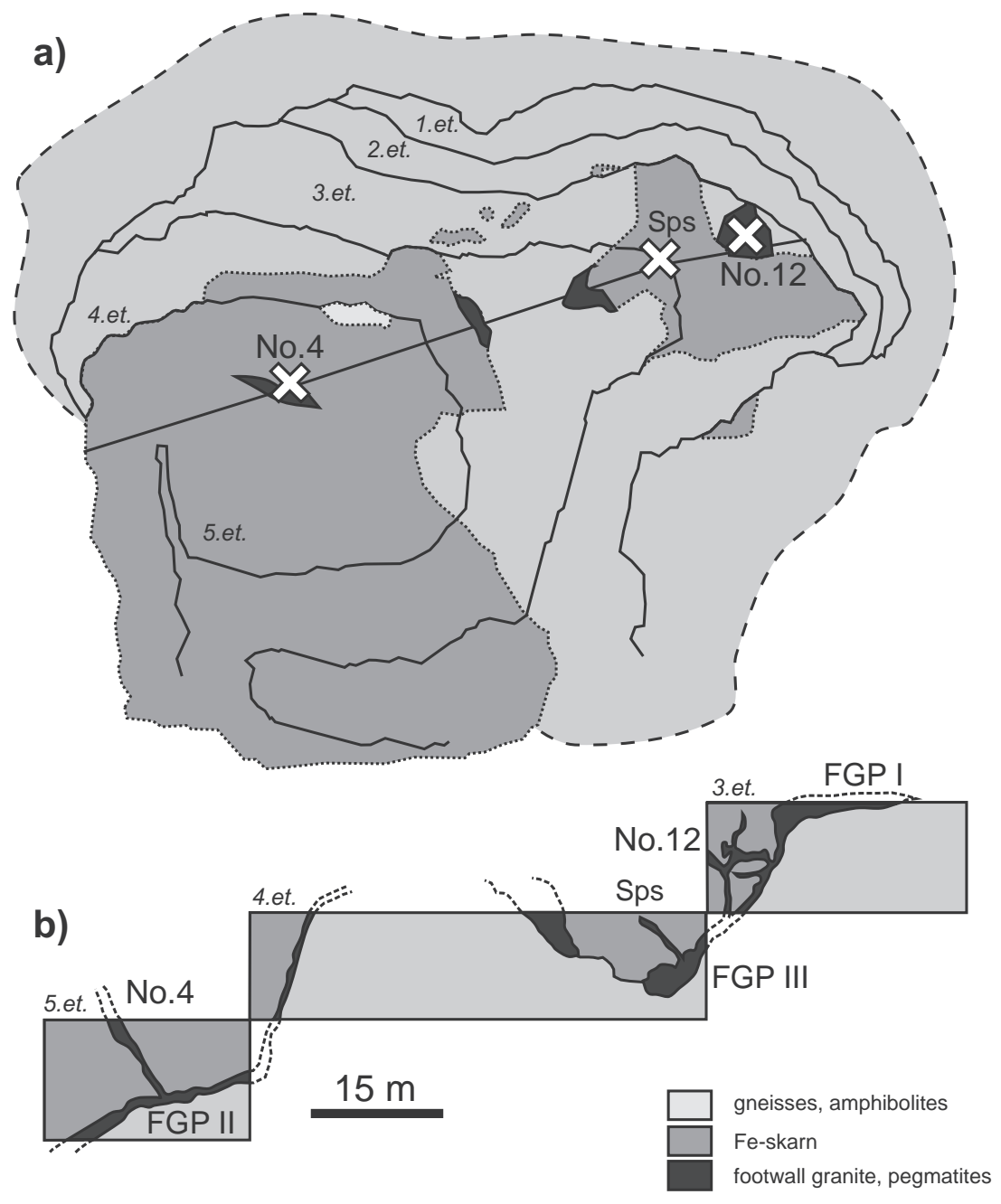

Fig. 5a Schematic geological map of the Holý vrch quarry. $\mathbf{b}-$ Cross section through the Fe-skarn, orthogneiss, Footwall granite-pegmatite and related tourmaline-bearing pegmatites. FGP - Footwall granite-pegmatite - granite I, II and III; Pegmatite No. 4; Pegmatite No. 12; Sps Spessartine pegmatite.

Tab. 3 Mineral assemblages of tourmaline-bearing pegmatites and pegmatites in orthogneiss

\begin{tabular}{|c|c|c|}
\hline Locality/reaction rims & Proportions of minerals & Accessory minerals \\
\hline Pegmatites in orthogneiss/absent & Tur-common; $\mathrm{Bt} \sim \mathrm{Ms}, \mathrm{Bt}>$ Tur & Ap, Zrn, phenakite \\
\hline Pegmatite Březina/absent & $\begin{array}{l}\text { Tur-common; Ms }>>\mathrm{Bt} \\
\text { Tur } \sim \mathrm{Grt}>\mathrm{Bt}\end{array}$ & Ap, Zrn, Rt, Ttn, Xtm, Mnz, Py, Sil \\
\hline Pegmatite Nosatá skála/absent & $\begin{array}{l}\text { Tur-common; Bt } \sim \text { Ms, } \\
\text { Tur }>\text { Bt }>\text { Grt }\end{array}$ & Ap, Zrn, Rt, Ttn, Xtm, Mnz, Py, Dsp, Ilm \\
\hline Footwall granite pegmatite/minor & Tur-very rare; $\mathrm{Bt} \gg>>$ Tur $>$ Amp & Ap, Py, Rt, Zrn, Aln, Ant, Bi-sulphide \\
\hline Pegmatite No. $12 /$ moderate & Tur-rare; Bt $>>$ Tur $\sim$ Amp & Ap, Ttn, Zrn, Py, Po, Aln, Cst, Rt, Fl \\
\hline Pegmatite No. 4/minor & Tur-rare; Bt $>>$ Tur $>$ Amp & Ap, Ttn, Zrn, Py, Apy, Cal \\
\hline Spessartine pegmatite/absent & Tur-rare; Bt $>$ Tut $>$ Grt & $\begin{array}{l}\text { Ap, Ttn, Zrn, Py, Apy, Ep, Cal, Fl, Sp, Cst, Y-rich milarite, uraninite, } \\
\text { Nb-rich rutile, minasgeraisite-(Y), Sn-rich titanite }\end{array}$ \\
\hline Elbaite pegmatite/absent (Čech 1985) & Tur-common; Tur $>>\mathrm{Bt}$ & $\begin{array}{l}\text { Ap, Fl, Zrn, Py, Cst, Mag, Elb, manganocolumbite, pyrochlore-group } \\
\text { minerals, danburite, datolite, bavenite, stokesite }\end{array}$ \\
\hline
\end{tabular}

Mineral assemblages from the authors' observations including data of Staněk and Schnorrer (1983), Čech (1985) and Povondra et al. (1985). 
facies), blocky K-feldspar and massive quartz locally with small pockets. The pegmatite discordantly cuts pyroxene paragneisses with thin intercalations of calcite marbles. Both the Březina and Nosatá skála pegmatites show sharp contacts with the country-rock paragneisses and no reaction rims.

The Footwall granite-pegmatite dike $(\mathrm{Qz}+\mathrm{Kfs}+\mathrm{Pl}$ $+\mathrm{Bt}$ ) occurs along the footwall contact of the Fe-skarn with the underlying orthogneiss at Holý vrch (Figs 3a, 5, $6 \mathrm{a}-\mathrm{b}, \mathrm{d})$. This complicated and tectonically fragmented dike is at least $\sim 250 \mathrm{~m}$ long and $\sim 1$ to $\sim 10 \mathrm{~m}$ thick in the outcrops (Fig. 5). The heterogeneous granite-pegmatite body consists of three texturally different facies. A medium- to coarse-grained and locally porphyritic granite I is located exclusively in the north-eastern upper corner of the quarry. A coarse-grained, subhomogeneous granite II, locally with anhedral grains of K-feldspar, occurs in the southwestern part of the body (the lower part of the quarry). The most evolved and less abundant, coarsegrained granite III (Fig. 5), with large subhedral crystals of blocky K-feldspar, locally up to $30 \mathrm{~cm}$ in size (Fig. 6e), cropped out in the centre of the quarry (Fig. 5). Graphic intergrowths of Qz with Kfs are locally common in the granites II and III. The granitic rocks are occasionally strongly altered to a mixture of clay minerals and quartz. Contacts with the host orthogneiss and Fe-skarn are mostly sharp. Only exceptionally a reaction zone with amphibole, up to $3 \mathrm{~cm}$ thick, occurs along the contact with the Fe-skarn; however the contact was often tectonically modified. Chemical analysis of the granite I is given in Tab. 1 .

The Pegmatite No. 12 was evidently derived from the least evolved granite I (Figs 5, 6a). The pegmatite forms a matrix of brecciated Fe-skarn with a complex morphology (Fig. 6a). The individual parts of the pegmatite body are from several $\mathrm{dm}$ up to $1 \mathrm{~m}$ thick in the current outcrops. A medium- to coarse-grained unit $(\mathrm{Qz}+\mathrm{Kfs}$ $+\mathrm{Pl}+\mathrm{Bt})$, with very rare tourmaline and amphibole, resembles the parental granite I as the typical pegmatitic textures (e.g., graphic intergrowths $\mathrm{Qz}+\mathrm{Kfs}$ ) are absent. This body exhibits reaction rims at the contact with the host Fe-skarn and its enclaves, up to $10 \mathrm{~cm}$ thick, with common greenish-black subhedral grains of amphibole, and locally rare pyrite, pyrrhotite, fluorite, allanite-(Ce) and other accessory minerals (Tab. 3 ).

Pegmatite No. 4 occurs as an elongated subhomogeneous dike, up to $1 \mathrm{~m}$ thick and $\sim 20 \mathrm{~m}$ long (Fig. $6 \mathrm{~b}$ ), consisting exclusively of a coarse-grained unit (Qz + $\mathrm{Kfs}+\mathrm{Pl}+\mathrm{Bt}+\mathrm{Tur}+\mathrm{Amp})$. Typical pegmatitic textures (e.g., graphic intergrowths) are rare. This pegmatite was evidently derived from the granite II (Figs 5, 6b) and the textures of the granite and pegmatite are mutually very similar. The pegmatite shows sharp to locally transitional contacts with the host Fe-skarn. The reaction zone is only several mm thick (Fig. 6c) with more abundant biotite in the adjacent pegmatite and rare amphibole at both endoand exocontacts with the Fe-skarn.

The elongated dike of the Spessartine pegmatite, up to $0.5 \mathrm{~m}$ thick and $\sim 15 \mathrm{~m}$ long, was evidently derived from the most evolved granite III (Figs 5, 6d). It consists of a dominant coarse-grained unit $(\mathrm{Qz}+\mathrm{Kfs}+\mathrm{Pl} \pm$ Tur) with only locally developed patches of graphic unit (Kfs + Qz), blocky K-feldspars, small quartz core and medium-grained albite. The latter contains small masses of fluorite and several accessory minerals including abundant spessartine (Tab. 3). The pegmatite evolved to massive quartz in the upper tip of the dike. Contact with the host Fe-skarn is typically sharp; no reaction rims were observed in hand specimens (Fig. 6f).

Elbaite pegmatite occurred in the western part of the Holý vrch Fe-skarn body close to the Spessartine pegmatite. It was completely mined out in 1982 and its internal structure and individual minerals were briefly described (Čech 1985; Povondra et al. 1985; Selway 1999; Ackerman et al. 2007). The pegmatite dike, up to $\sim 2 \mathrm{~m}$ thick, exhibited simply zoned internal structure with a fine- to medium-grained outer zone $(\mathrm{Qz}+\mathrm{Kfs}+\mathrm{Pl} \pm \mathrm{Bt} \pm$ Tur $)$, coarse-grained inner zone $(\mathrm{Qz}+\mathrm{Kfs}+\mathrm{Pl}+$ Tur $)$ with abundant graphic intergrowths (Qz + Kfs, Qz + Tur), blocky K-feldspar, albite, and rare pockets containing crystals of albite, K-feldspar, smoky quartz and red fluorelbaite (Tab. 3). No samples from the contact with the host Fe-skarn were available for our study; however, the contacts were described as sharp (Čech 1985; P. Povondra pers. comm. 2010).

\subsubsection{Mineralogy}

The tourmaline-bearing pegmatites always contain minor to accessory biotite (Tab. 3). The amount of tourmaline varies from a very rare to rare accessory mineral in the Footwall granite-pegmatite and in the Pegmatite No. 12, through an accessory phase in the Spessartine pegmatite to a frequent (locally minor) mineral in pegmatites from paragneisses and in the Elbaite pegmatite. Primary muscovite is common only in the pegmatite bodies hosted by gneisses but absent in all pegmatites cutting the Fe-skarn. Amphibole is absent in all pegmatites from paragneisses, Spessartine pegmatite and Elbaite pegmatite, it is rare in the Pegmatite No. 4 and Pegmatite No. 12 (Tab. 3). Euhedral grains of garnet are abundant in both pegmatites from paragneisses (Tab. 3) but absent in the bodies cutting the Fe-skarn except for the Spessartine pegmatite.

The assemblage of accessory minerals in the tourmaline-bearing pegmatites is dominated by fluorapatite. Also magnetite, zircon, rutile, titanite, monazite-(Ce), xenotime-(Y), allanite-(Ce), ilmenite, 

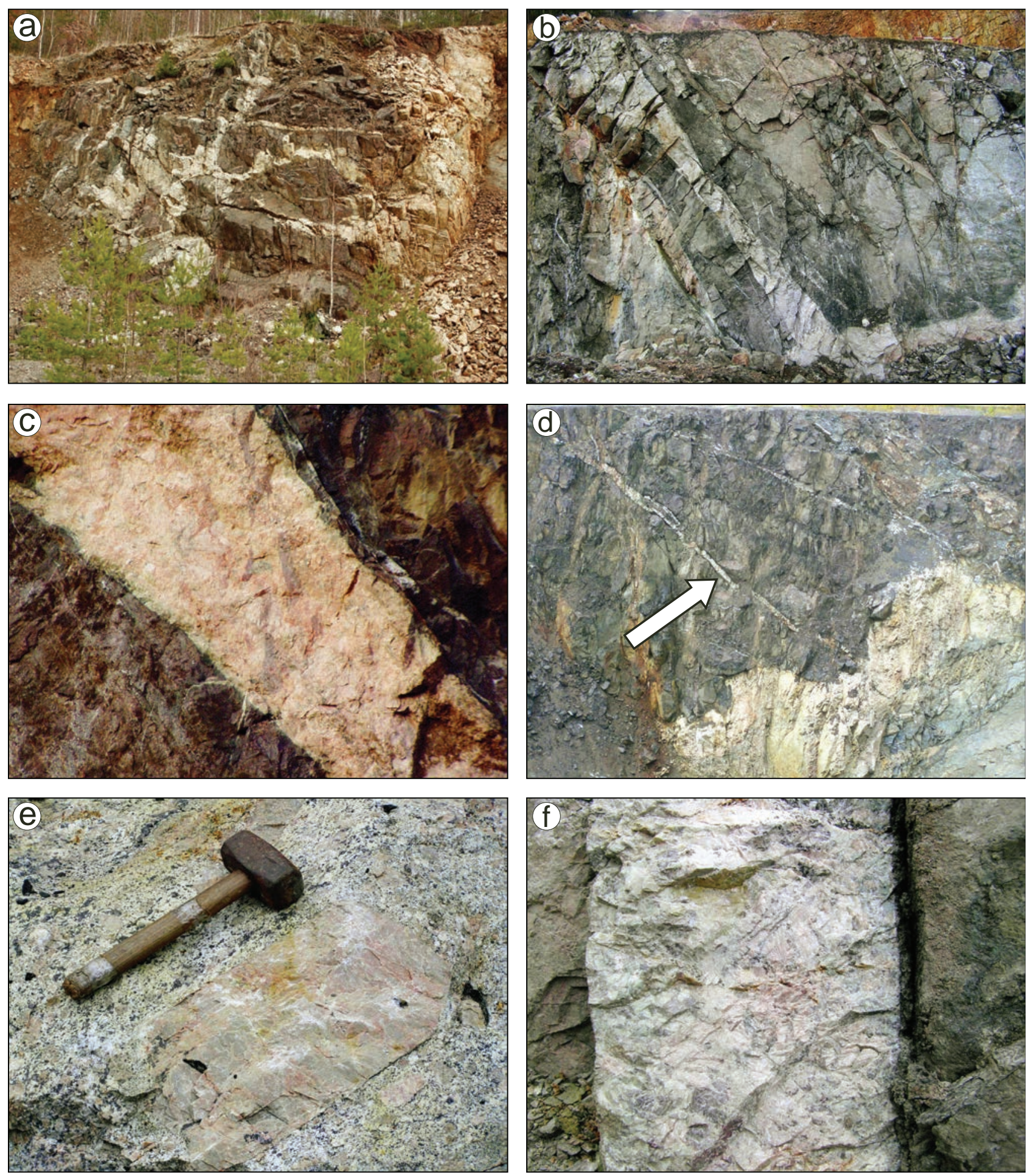

Fig. 6 Tourmaline-bearing pegmatites cutting the Fe-skarn: a - Footwall granite-pegmatite (granite I - right side) and Pegmatite No. 12 (left side); b - Footwall granite-pegmatite (granite II) and Pegmatite No. 4 up to $1 \mathrm{~m}$ thick; c - detail of the Pegmatite No. 4 , about $30 \mathrm{~cm}$ thick, note thin reaction rim with amphibole in garnet skarn (left footwall); $\mathbf{d}$ - Footwall granite-pegmatite (granite III) and thin dike of the Spessartine pegmatite up to $50 \mathrm{~cm}$ thick, marked by an arrow; e - large crystal of K-feldspar with grains of black tourmaline in the Footwall granite-pegmatite (granite III); f - detail of the Spessartine pegmatite, note sharp contacts. Field situation on 28 March 2009 (a), 19 January 2007 (b), 10 December 2004 (c), 2 June 2009 (d), 6 July 2007 (e) and 31 March 2007 (f). Photo T. Kadlec. 


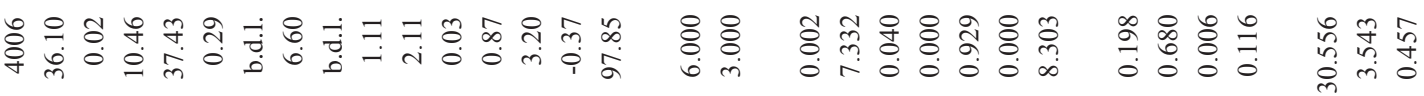

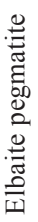

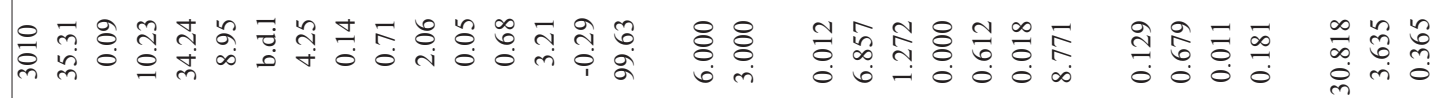

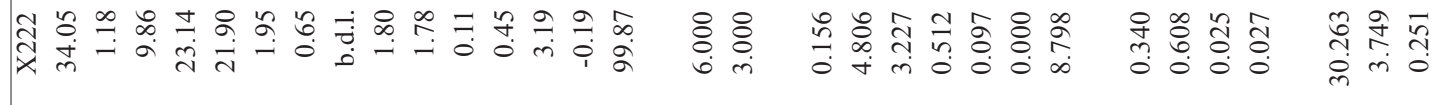

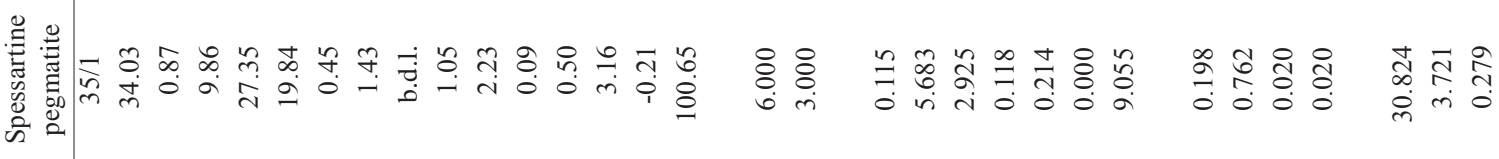

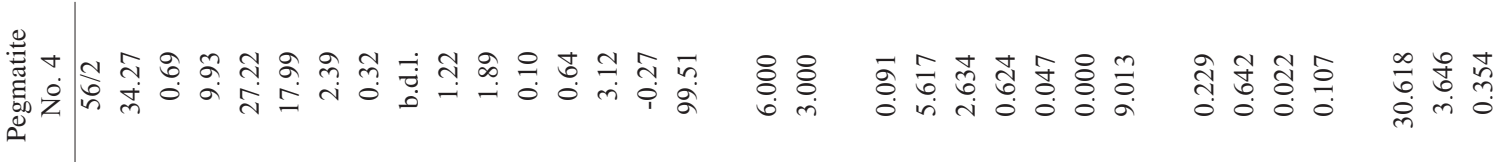

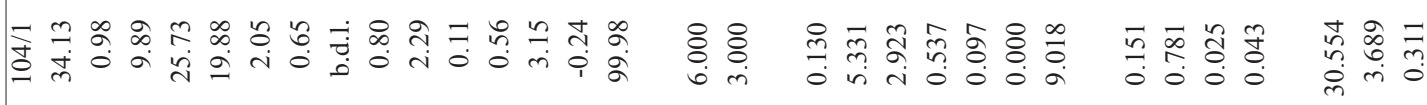
莺乞

存

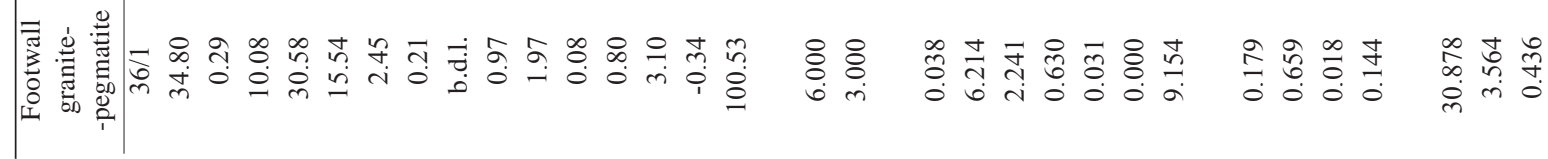

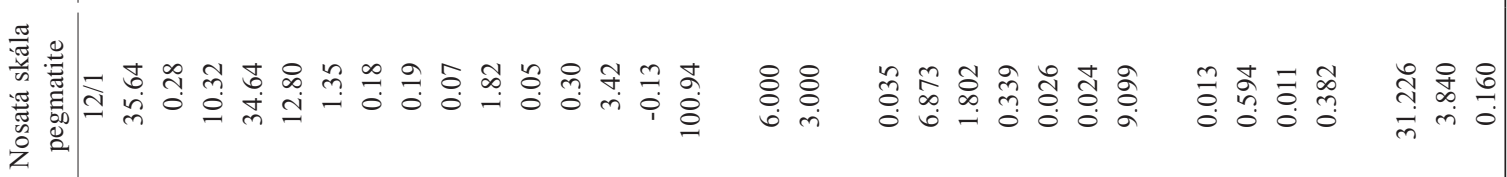

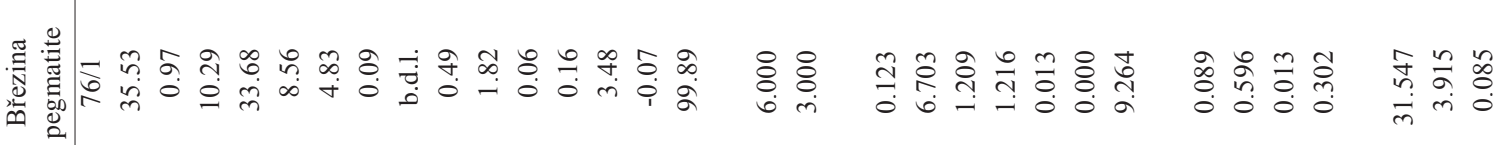

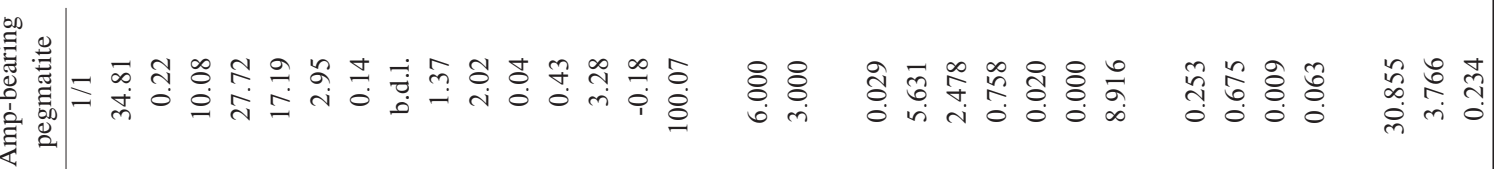

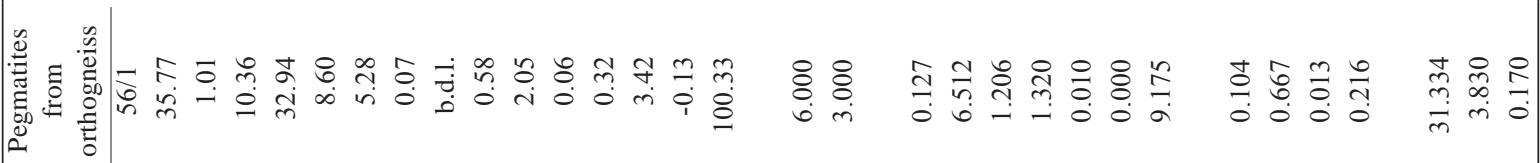

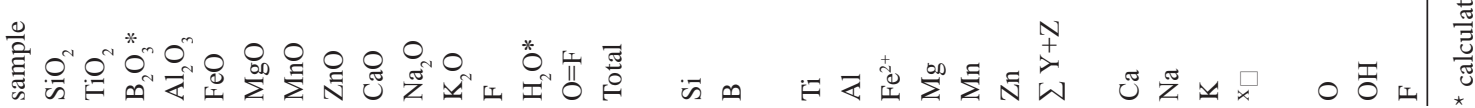


arsenopyrite, and pyrite are present in most pegmatite bodies (Tab. 3). Fluorite as small violet grains and masses occurs either in the more evolved Spessartine pegmatite and Elbaite pegmatite but also in direct contact with the Fe-skarn in the primitive Pegmatite No. 12. Further details concerning the pegmatite (granite) dikes examined and review of all minerals identified from the individual tourmaline-bearing pegmatite dikes are given in Tab. 3.

Ackerman et al. (2007) inferred, based on the detailed study of fluid inclusions and geological constraints (geothermal gradient, haplogranite solidus with $4.5 \mathrm{wt} \%$ $\mathrm{B}_{2} \mathrm{O}_{3}$, feldspars thermometry), the following conditions for the Elbaite pegmatite formation: $\mathrm{P}=0.31-0.43 \mathrm{GPa}$, $\mathrm{T}=500-570{ }^{\circ} \mathrm{C}$; the host-rock temperature during pegmatite emplacement was estimated at $\sim 300^{\circ} \mathrm{C}$.

\section{Chemical composition of minerals}

\subsection{Tourmaline}

Tourmalines (schorl, dravite, foitite, elbaite, fluor-elbaite) from the individual types of pegmatites enclosed in the orthogneiss, amphibole-bearing pegmatites hosted by the Fe-skarn, and mainly tourmaline-bearing pegmatites cutting the paragneisses and Fe-skarn including Footwall granite-pegmatite, differ significantly in their chemical compositions (Tab. 4). Because tourmaline forms fine-grained intergrowths with secondary Fe-rich chlorite in all tourmaline-bearing pegmatites cutting the Fe-skarn (Fig. 7a-b) except for the Elbaite pegmatite and scarcely the Pegmatite No. 12 (Fig. 7c), determination of $\mathrm{Fe}^{2+} / \mathrm{Fe}^{3+}$ by Mössbauer spectroscopy (see e.g., Novák et al. 2011) was not possible. The individual tourmaline grains are commonly slightly heterogeneous (Fig. 7c).

\subsubsection{X-site}

Two groups of tourmalines are evident in Fig. 8a, Ca-poor $(\mathrm{Ca}<0.15 \mathrm{apfu}$, moderate to high proportion of vacancy in the X-site) (Březina and Nosatá skála pegmatites cutting paragneisses, pegmatite in orthogneiss) and Ca-rich $(\mathrm{Ca}=0.15-0.47 \mathrm{apfu}$, low to moderate $\mathrm{X}$-site vacancy, $\mathrm{x}_{\square} \leq 0.25 \mathrm{pfu}$ ) (all pegmatites enclosed in the Fe-skarn, including rare fibrous tourmaline from amphibole-bearing pegmatite). Tourmaline compositions from the individual dikes are scattered over a fairly large field (Fig. 8a).

\subsubsection{Y-site and Z-site}

Extremely high variability in $\mathrm{Al}$ contents of the individual tourmalines $\left(\mathrm{Al}_{\mathrm{tot}}=4.81-8.29 \mathrm{apfu}\right)$ is the most typi- cal feature. Pegmatites enclosed in the para- (Březina, Nosatá skála) and orthogneisses, Footwall granitepegmatite and part of tourmaline (with high elbaite component) from the Elbaite pegmatite (Fig. 8b) have $\mathrm{Al}_{\text {tot }}$ greater than 6 apfu and thus they correspond to ordinary tourmalines from granitic pegmatites (Selway et al. 1999; Novák et al. 2004). Tourmalines from all tourmaline-bearing pegmatites cutting the Fe-skarn and, rarely, the amphibole-bearing pegmatite are Al-poor, including Spessartine pegmatite (5.20-5.59 apfu Al) and black schorl from the Elbaite pegmatite (4.81-6.26 apfu Al) (Fig. 8b). Tourmalines from pegmatites cutting the Fe-skarn mostly having $\mathrm{Al}_{\text {tot }}<6$ indicate the presence of $\mathrm{Fe}^{3+}$. The wet chemical analysis of schorl from the Elbaite pegmatite showed elevated $\mathrm{Fe}^{3+}$ of 0.54 apfu (Povondra et al. 1985). Tourmalines from pegmatites in para- and orthogneisses have clearly higher contents of $\mathrm{Mg}(\mathrm{Mg} /(\mathrm{Fe}+\mathrm{Mg})=0.22-0.52$; Fig. $8 b)$ than from the Footwall granite-pegmatite and primitive pegmatites cutting the Fe-skarn (Pegmatites No. 12 and No. 4; Mg/ $(\mathrm{Fe}+\mathrm{Mg})=0.20-0.24)$. Tourmaline from orthogneiss with $\mathrm{Mg} /(\mathrm{Fe}+\mathrm{Mg})=0.42-0.53$ is the least fractionated. Evidently the most fractionated are the Spessartine pegmatite and the Elbaite pegmatite $((\mathrm{Mg} /(\mathrm{Fe}+\mathrm{Mg})=$ $0.07-0.10$ and $0.00-0.16$, respectively), whereby the values close to 0 are typical of elbaite and associated schorl. Tourmaline from the Elbaite pegmatite (elbaite, fluor-elbaite) is also significantly enriched in Mn (up to $0.31 \mathrm{apfu}$ - wet chemical analyses of Povondra et al. 1985, or even 0.93 apfu $\mathrm{Mn}$, electron microprobe data; Tab. 4) as is common in elbaite-subtype pegmatites (Novák and Povondra 1995; Novák 2000; Novák et al. 1999a, 2012). Low to moderate contents of Ti (0.03-0.16 apfu) are characteristic of tourmaline from all examined pegmatites; slightly higher concentrations of Ti were found in pegmatites enclosed in the Fe-skarn (Tab. 4). High surplus of $Y+Z$ in most of analyses of black tourmaline (Tab. 4) imply that the normalization on the basis of 6 apfu Si and $\mathrm{OH}+\mathrm{F}=4$ is not ideal and that an oxy-tourmaline component is present along with $\mathrm{Fe}^{3+}$ and perhaps ${ }^{\mathrm{T}} \mathrm{Al}$ (Povondra et al. 1985; Novák et al. 2004; Bačík et al. 2013).

\subsubsection{W-site}

Concentrations of $\mathrm{F}$ vary from low in tourmalines from the pegmatites enclosed in para- and orthogneisses (0.01-0.21 apfu) to moderate in tourmaline-bearing pegmatites cutting the Fe-skarn (0.24-0.37); the highest concentrations of F (0.31-0.46 apfu) were found in the Footwall granite-pegmatite dike. Tourmalines in the Elbaite pegmatite show much higher variation from 0.22 apfu $F$ in black schorl to 0.56 apfu $F$ in red fluor-elbaite. 

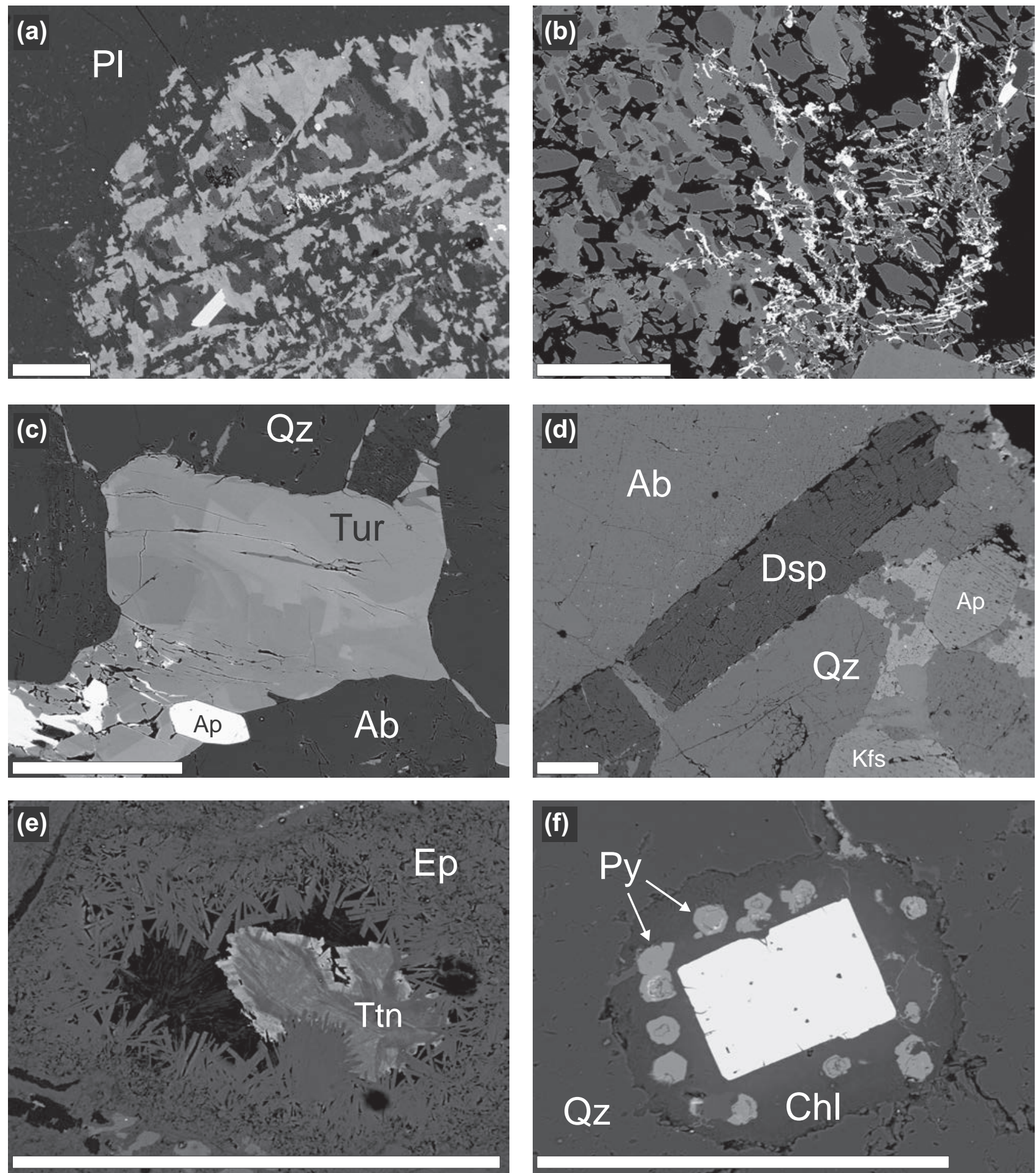

Fig. 7 Back-scattered electron (BSE) images of selected minerals: a - euhedral tourmaline with secondary chlorite (bright) in dark plagioclase (Pl) from the Footwall granite-pegmatite; b - tourmaline (dark) with secondary chlorite (grey) and late titanite (bright veinlets), Březina pegmatite; c - zoned subhedral tourmaline (Tur) in association with quartz (Qz), albite (Ab), and apatite (Ap) from the Pegmatite No. 12; d - diaspore (Dsp) in albite $(\mathrm{Ab})$ and quartz $(\mathrm{Qz})$, in association with K-feldspar (Kfs) and apatite (Ap), Nosatá skála pegmatite; e - zoned titanite (Ttn) with Sn-rich rim associated with epidote (Ep), Spessartine pegmatite; $\mathbf{f}$ - euhedral crystal of uraninite (bright) in quartz (Qz), see pyrite (Py) in chlorite rim (Chl), Spessartine pegmatite. Scale bar $=250 \mu \mathrm{m}$. 


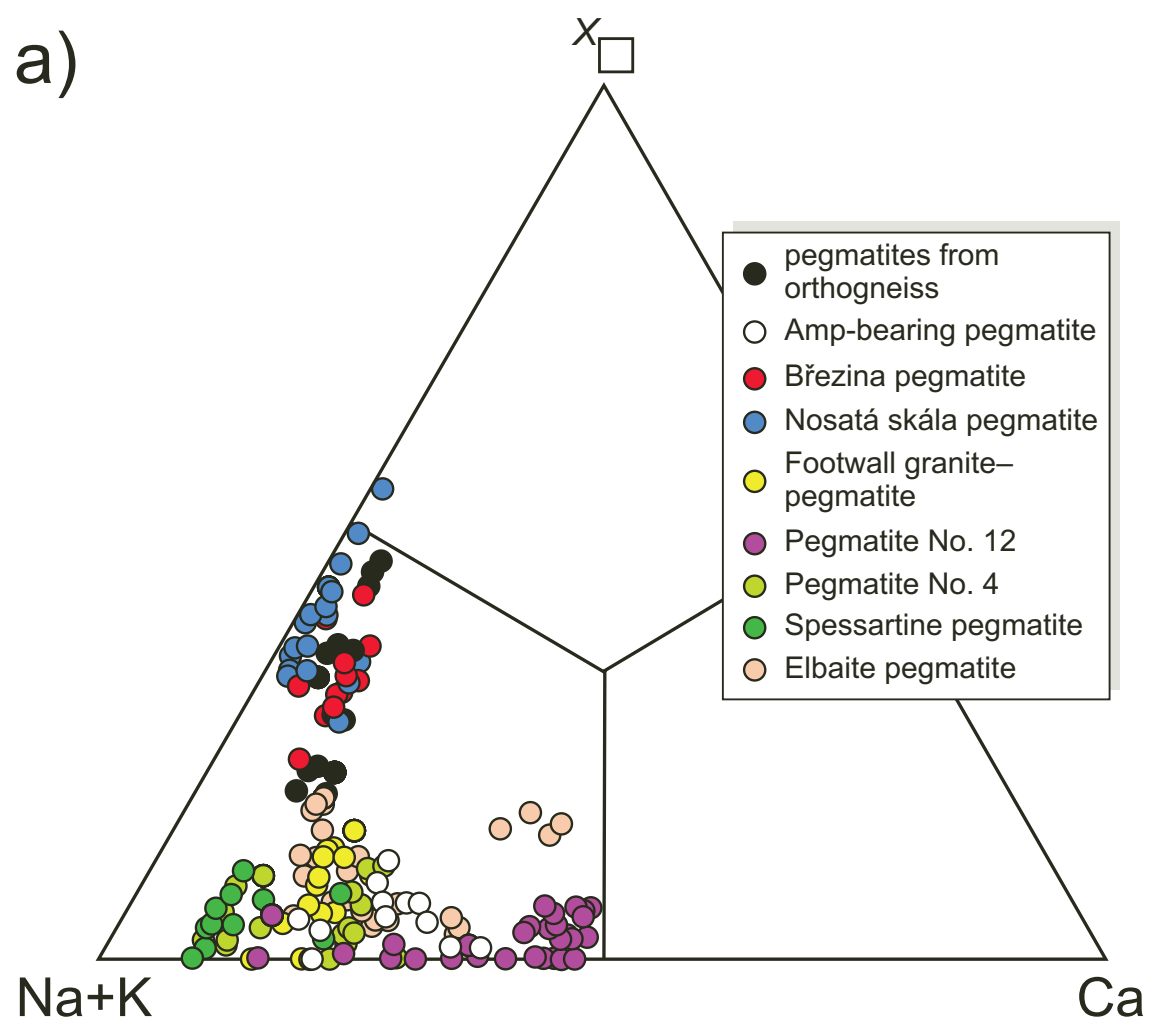

b)

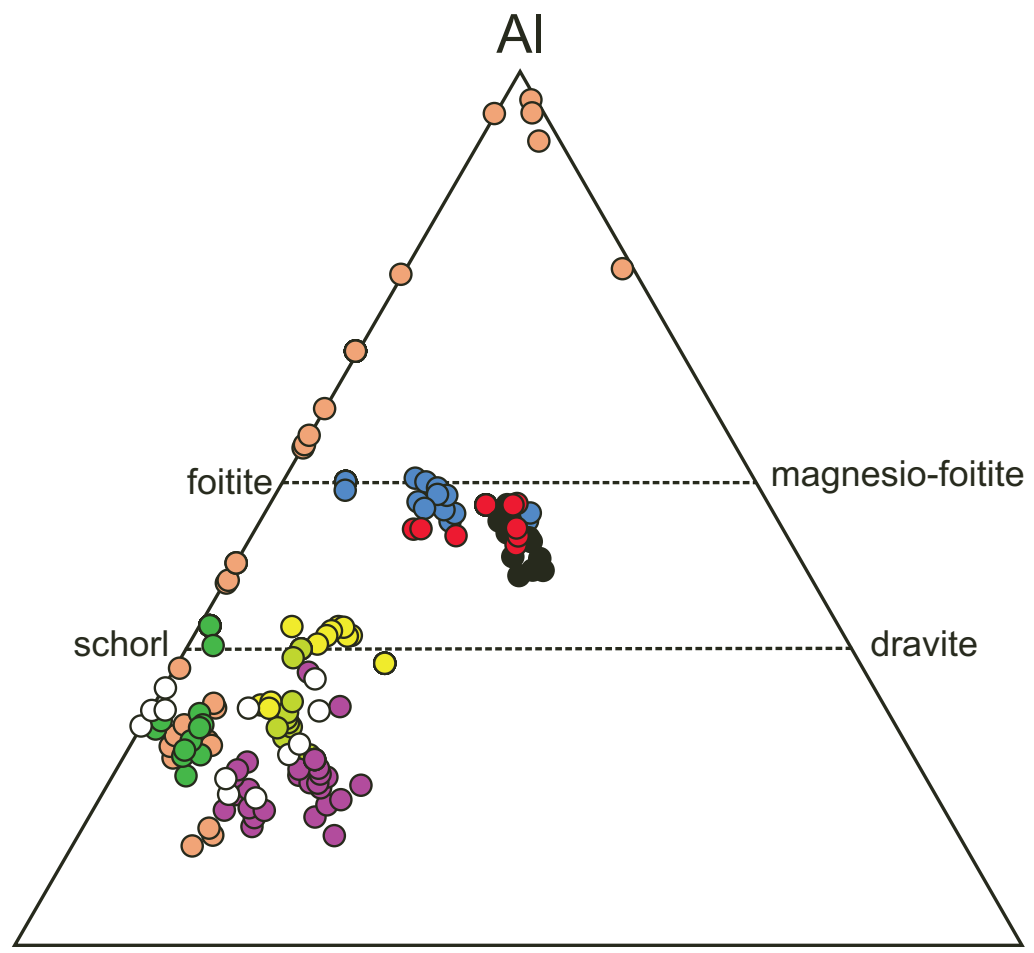

$\mathrm{Fe}_{50} \mathrm{Al}_{50}$

$\mathrm{Mg}_{50} \mathrm{Al}_{50}$

Fig. 8 Compositional diagrams of tourmaline from granitic pegmatites in the Vlastějovice region: $\mathbf{a}-(\mathrm{Na}+\mathrm{K})$ - vacancy in the X-site $-\mathrm{Ca} ; \mathbf{b}-\mathrm{Fe}-\mathrm{Al}-\mathrm{Mg}$.

\subsection{Biotite, muscovite and chlorite}

Biotite is common to rare in all pegmatite groups but typically more or less chloritized, especially in the tourmaline-bearing pegmatites and thus a detailed discussion of its chemistry is not feasible. Biotite from all pegmatites is Fe-rich showing low variation in $\mathrm{Mg} /(\mathrm{Mg}+\mathrm{Fe})$ (Fig. 9a) and is enriched in $\mathrm{F}$ (0.08-0.42 apfu). Muscovites from pegmatites cutting the para- and orthogneisses are all similar $(\mathrm{Al}=2.74-2.91, \mathrm{Si}=$ $3.03-3.07, \mathrm{Fe}=0.04-0.08, \mathrm{Mg}$ $=0.02-0.07$ and $\mathrm{F}=0.02-0.07$ apfu). Also secondary chlorites are Fe-rich; chamosite replacing tourmaline in pegmatites from the Fe-skarn has $\mathrm{Si}=2.58$ 2.78 apfu and $\mathrm{Mg} /(\mathrm{Mg}+\mathrm{Fe})=$ $0.05-0.21$, i.e. resembling the replaced tourmaline. Secondary chamosite after biotite has $\mathrm{Mg} /(\mathrm{Mg}+\mathrm{Fe})=0.01-0.35$, i.e. comparable with the precursor. It differs from secondary chlorite after tourmaline by slightly higher Si of 2.70-2.98 apfu.

\subsection{Amphibole}

Amphiboles from amphibolebearing pegmatites cutting the Fe-skarn were examined in detail by Žáček and Povondra (1991) and Žáček (2007). They show similar $\mathrm{Mg} /(\mathrm{Mg}+\mathrm{Fe})$ of 0.13-0.25 in amphibolebearing pegmatites (hastingsite to potassichastingsite; $\mathrm{K} \leq 0.65$ apfu and $\leq 3.15$ wt. $\% \mathrm{~K}_{2} \mathrm{O}$ ) and of $0.11-0.29$ in tourmaline-bearing pegmatites with Footwall granite-pegmatite (potassian hastingsite with $\leq$ $0.4 \mathrm{~K}$ apfu and $\leq 1.77$ wt. $\%$ $\mathrm{K}_{2} \mathrm{O}$ to potassian ferro-edenite with $\leq 0.37 \mathrm{~K}$ apfu and $\leq 1.64$ wt. $\% \mathrm{~K}_{2} \mathrm{O}$; Fig. 9 b). Contents 
of $\mathrm{Si}$ increase from 6.05 to 6.70 apfu, together with $\mathrm{Mg} /$ $(\mathrm{Mg}+\mathrm{Fe})$ (Fig. 9b). In the tourmaline-bearing pegmatites, hastingsite is typical of exocontacts and ferro-edenite of endocontacts, respectively.

\subsection{Garnet}

Subhedral grains and their aggregates of brownish red andradite-grossular, up to $2 \mathrm{~cm}$ in size, are typical of some amphibole-bearing pegmatites (Tab. 2). They are slightly heterogeneous in composition (Fig. 10). Almandine-dominant garnets from both tourmaline-bearing pegmatites in the paragneisses (Březina and Nosatá skála) are only slightly heterogeneous in the BSE images; garnet from the Březina pegmatite is slightly enriched in $\mathrm{Mg}$ and $\mathrm{Ca}$ (Fig. 10). By comparison, spessartine-dominant garnet from the Spessartine pegmatite is evidently enriched in $\mathrm{Ca}, \mathrm{Mn}$ and $\mathrm{Fe}^{3+}$ (Fig. 10). Both the higher degree of fractionation expressed by higher $\mathrm{Mn} /(\mathrm{Mn}+\mathrm{Fe})$ and strong Ca,Fe-contamination are recorded in this garnet. It is also enriched in $\mathrm{Y}$ (up to 0.02 apfu, i.e. up to 0.41 wt. \% $\mathrm{Y}_{2} \mathrm{O}_{3}$ ). Elevated contents of $\mathrm{Y}$ were found only exceptionally in Czech pegmatites (Hönig et al. 2010; Novák et al. 2012).

\subsection{Feldspars}

Composition of plagioclase $\left(\mathrm{An}_{0-32}\right.$; see also Ackerman et al. 2007) does not show any apparent differences among the individual pegmatite types; in particular, high variation in $\mathrm{Na} / \mathrm{Ca}$ is typical. For instance, plagioclase attains up to $\mathrm{An}_{15}$ in the pegmatites from the orthogneiss, $\mathrm{An}_{25}$ in the Březina pegmatite, $\mathrm{An}_{31}$ in plagioclase associated with fluorite from the Pegmatite
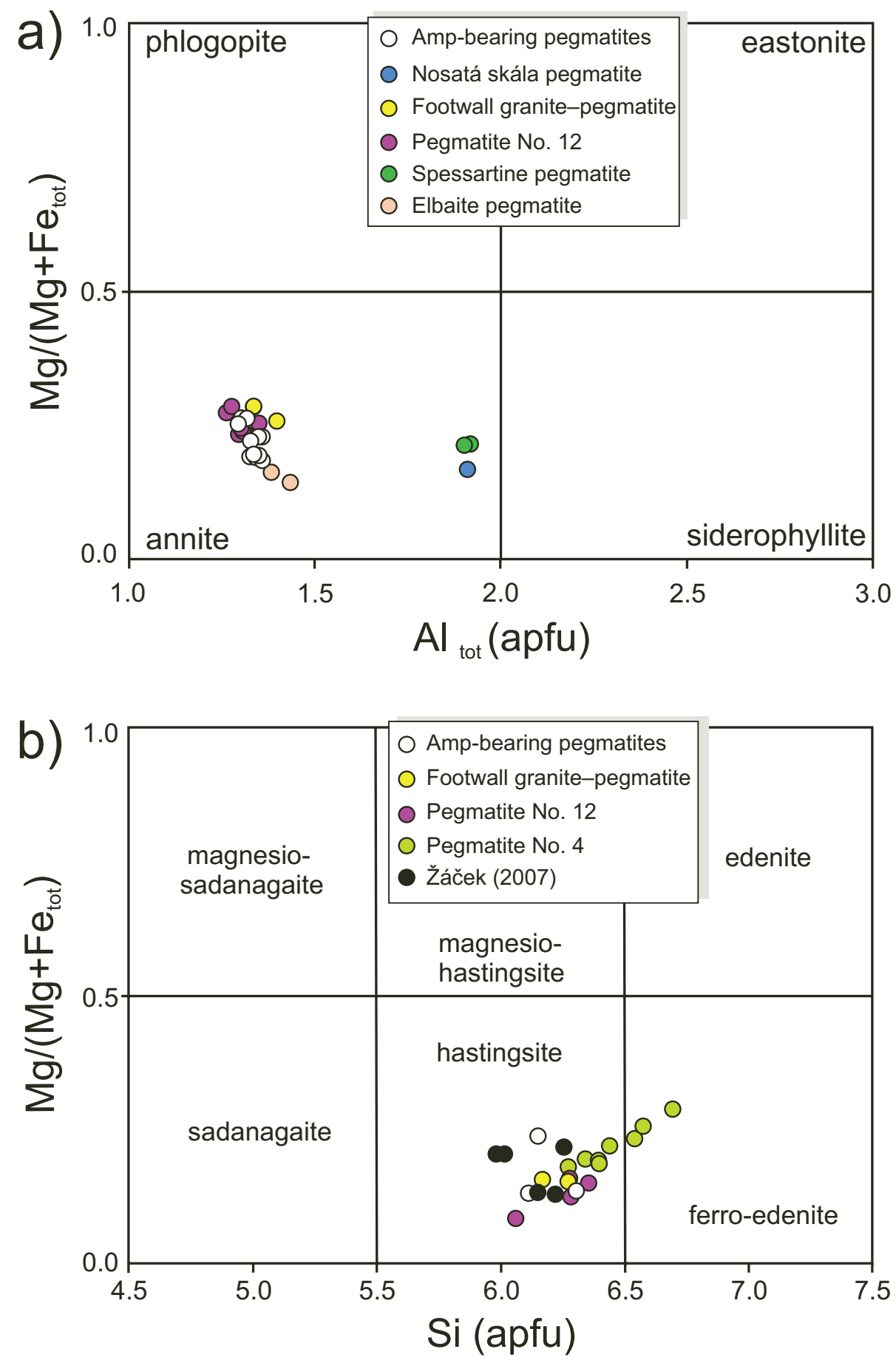

Fig. 9 Compositional diagrams for biotite (a), and amphibole (b) (Leake et al. 1997) from granitic pegmatites in the Vlastějovice region. Amphibole analyses from ampfibole-bearing pegmatites taken from Žáček and Povondra (1991) and Žáček (2007).

No. 12 and up to $\mathrm{An}_{32}$ in the amphibole-bearing pegmatites. Compositions of perthitic K-feldspar vary from almost pure $\mathrm{KAlSi}_{3} \mathrm{O}_{8}$ to $\mathrm{Or}_{85} \mathrm{Ab}_{15}$ and no significant differences were found among the individual pegmatite types, either. 


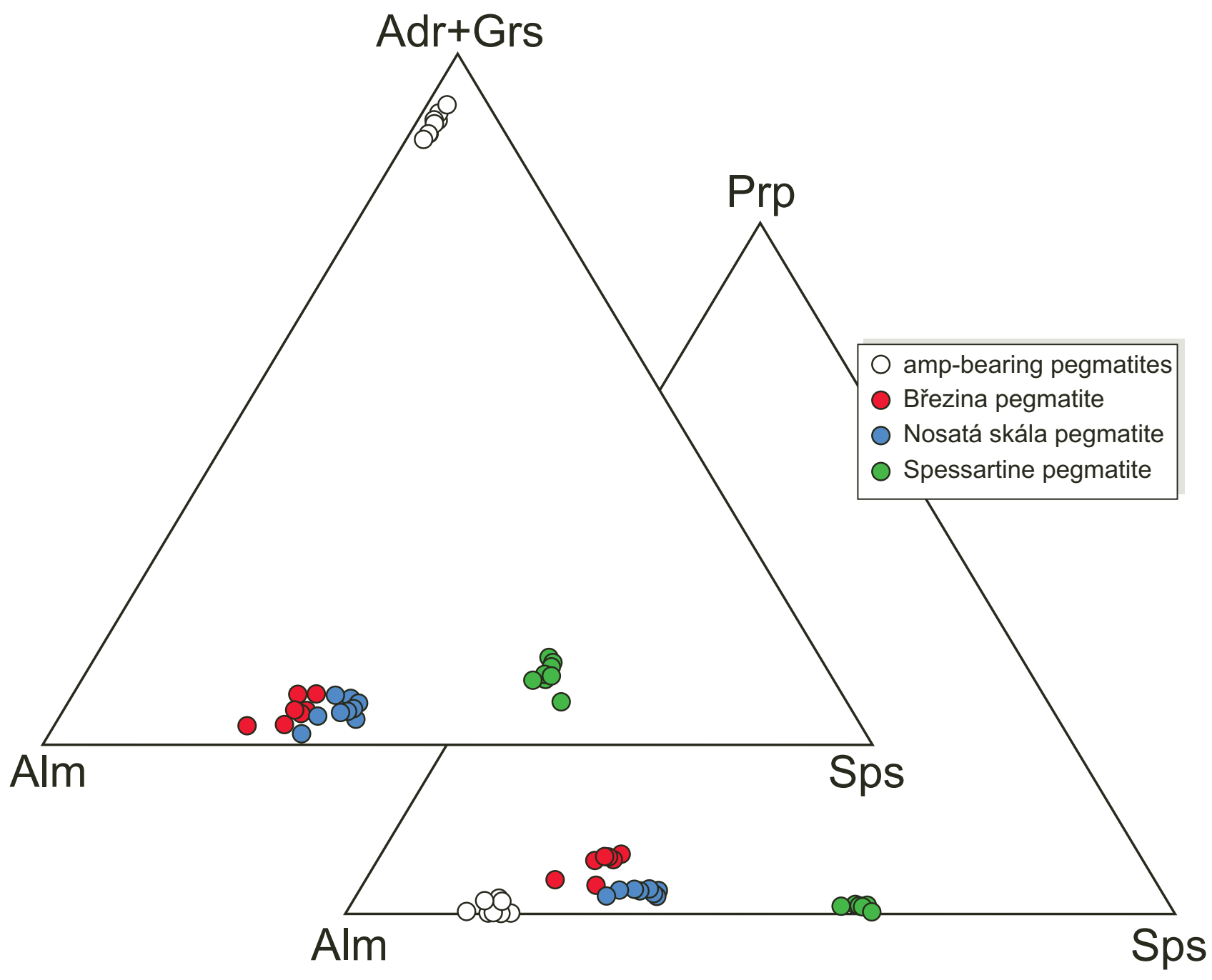

Fig. 10 Compositional diagrams of garnet from granitic pegmatites in the Vlastějovice region (mol. \%).

\subsection{Chemical composition of the selected accessory minerals}

Tourmaline-bearing pegmatites contain several accessory minerals (see Tab. 3, Fig. 7d-f). Most of them apparently indicate an elevated degree of fractionation in the parental granitic rock. Empirical formulae of selected minerals are given below. The Spessartine pegmatite contains several less common to very rare accessory phases with unusual compositions: Sn-rich titanite $-\mathrm{Ca}_{1.02}\left(\mathrm{Ti}_{0.61}\right.$ $\left.\mathrm{Sn}_{0.28} \mathrm{Al}_{0.09} \mathrm{Fe}_{0.04} \mathrm{Nb}_{0.01}\right)_{1.03} \mathrm{Si}_{1.00} \mathrm{O}_{4.93} \mathrm{~F}_{0.07}$ (Fig. 7e), Y-rich milarite - $\left(\mathrm{K}_{2.08} \mathrm{Na}_{0.04}\right)_{2.12}\left(\mathrm{Ca}_{2.24} \mathrm{Y}_{1.70} \mathrm{Fe}_{0.20} \mathrm{Mn}_{0.05}\right)_{4.19} \mathrm{Be}_{4.00}$ $\mathrm{Si}_{24.85} \mathrm{O}_{59.84} \mathrm{~F}_{0.16} \cdot \mathrm{H}_{2} \mathrm{O}$ and mineral close to minasgeraisite$(\mathrm{Y})-\mathrm{Ca}_{0.84}\left(\mathrm{Y}_{0.66} \mathrm{Fe}_{0.35} \mathrm{Yb}_{0.09} \mathrm{Er}_{0.05}\right)_{1.15} \mathrm{Be}_{2.0} \mathrm{Si}_{2.04} \mathrm{O}_{8}(\mathrm{OH})_{0.89}$ $\mathrm{F}_{0.11}$ the latter two as inclusions in spessartine. In the Elbaite pegmatite, "fluorcalciopyrochlore" $\left(\mathrm{Ca}_{1.14} \mathrm{Na}_{0.77}\right.$ $\left.\mathrm{Sb}_{0.01} \mathrm{U}_{0.01}\right)_{1.93}\left(\mathrm{Nb}_{1.40} \mathrm{Ta}_{0.52} \mathrm{Sn}_{0.07} \mathrm{Ti}_{0.01}\right)_{2.00} \mathrm{O}_{6} \mathrm{~F}_{1.17}$ and a secondary Bi-rich member of pyrochlore group $\left(\mathrm{Bi}_{0.78} \mathrm{Ca}_{0.36} \mathrm{Fe}_{0.33}\right.$ $\left.\mathrm{Pb}_{0.28} \mathrm{Mn}_{0.15} \mathrm{Sb}_{0.06} \mathrm{U}_{0.02}\right)_{1.64}\left(\mathrm{Nb}_{1.64} \mathrm{Ta}_{0.21} \mathrm{Sn}_{0.13} \mathrm{Ti}_{0.02} \mathrm{~W}_{0.01}\right)_{2.00} \mathrm{O}_{6}$ were found among the other accessory minerals (Tab. 3 ).

\section{Discussion}

The granitic pegmatites described from the Vlastějovice region differ significantly in their mineral assemblages, internal structure, host rocks and origin. Except for those enclosed in the orthogneiss, the amphibole-bearing pegmatites (various subtypes) were already described in numerous papers from Vlastějovice as well as from other localities in the Moldanubian Zone (see Novák 2005; Novák and Cempírek 2010 for review). We focused our research on the pegmatites enclosed in the orthogneiss, amphibole-bearing pegmatites and, in particular, the tourmaline-bearing pegmatites (Tabs 2-3) to demonstrate typical examples of various types of granitic pegmatites in the Moldanubian Zone.

\subsection{Pegmatites from orthogneisses}

The granitic pegmatites enclosed in tourmaline-bearing orthogneisses form rather small and uncomplicated bod- 
ies. Simple pegmatites from the Světlík orthogneiss (2.1 Ga; e.g., Wendt et al. 1993) were not studied in detail and they may represent the earliest granitic pegmatite population in the Moldanubian Zone.

The parental orthogneisses to the simple pegmatites distributed within the Varied Unit (Breiter et al. 2005a) were dated as Ordovician (Hluboká nad Vltavou; Vrána and Kröner 1995). Only localities Přibyslavice, Bechyně, Hamry nad Sázavou, and Vlastějovice were studied in detail and show rather distinct assemblages of accessory minerals (e.g., tourmaline, fluorapatite, beryl, topaz, löllingite, garnet - Hamry nad Sázavou; tourmaline, fluorapatite, zircon, phenakite - Vlastějovice; Novák 1981; Staněk and Schnorrer 1983; Povondra et al. 1987; Povondra 1989; Kadlec 2007a; Novák and Cempírek 2010). They also show variable internal structure from simply zoned elongated nests with rather sharp to slightly diffuse contacts against the foliated host orthogneiss (Vlastějovice) to irregular coarse-grained facies of orthogneiss with transitional contacts and small pockets (Hamry nad Sázavou). However, lack of geological and mineralogical data from these pegmatites hinders a detailed discussion of their relations and origin.

The pegmatites occurring in the Prribyslavice orthogneiss body are more variable and only the most primitive among them resemble the above localities in the simple mineral assemblages (Novák and Cempírek 2010); however, primitive pegmatites were not studied in detail. Apparently post-tectonic pegmatites with a variety of minerals including Li-bearing ones (triphylite, Li-mica, Li-tourmaline, amblygonite) and numerous accessory minerals (see Povondra et al. 1987; Novák and Cempírek 2010) are likely Variscan.

\subsection{Amphibole-bearing pegmatites}

Amphibole-bearing pegmatites, frequently with accessory allanite and fluorite, cutting Fe-skarn bodies are relatively common in the Moldanubian Zone (e.g., Rešice near Hrotovice, Lišná near Svratka, Domanínek near Bystřice nad Pernštejnem, Malešov near Kutná Hora; e.g., Němec 1963; Novák 2005; Novák and Cempírek 2010 and references therein). They exhibit simple internal structure (Fig. 3d) with dominant coarse-grained texture and locally with masses of quartz. At Vlastějovice, these masses are randomly distributed in the pegmatite bodies and do not resemble quartz core developed in many granitic pegmatites. Also further textural-paragenetic units typical of granitic pegmatites such as graphic intergrowths of quartz with K-feldspar or blocky K-feldspar are absent. Their $\mathrm{Ca}-\mathrm{Fe} \pm \mathrm{F}$-rich mineral assemblages, concentrated particularly along contacts of the pegmatite bodies (amphiboles, fluorite and allanite) (Fig. 4) and in pockets (prehnite, apophyllite) suggest strong but variable in situ contamination from host Fe-skarn. In the studied pegmatites from Vlastějovice, $\mathrm{Ca}$ and $\mathrm{Fe}$ obviously come from the skarn; common allanite-(Ce) also suggests intake of REE (Novák and Cempírek 2010). Fluorine was likely derived from an early F-rich garnet $\left(\mathrm{Grs}_{79-87} \mathrm{And}_{12-18}\right.$; $\mathrm{F}=0.82-1.18$ wt. \%) preserved extensively as relics in newly-formed garnets $\left(\mathrm{Grs}_{12-52} \mathrm{And}_{40-71} \mathrm{Alm}_{2-14} \mathrm{Sps}_{0-2} ; \mathrm{F}=\right.$ $0.10-0.25$ wt. \%), which originated during an early stage of MP-HT regional metamorphism of the host Fe-skarn (Žáček 1997; Žáček et al. 2003). Fluorine-rich garnet is known also from other Fe-skarn localities in the Moldanubian Zone (Pertoldová et al. 2009; S. Houzar, pers. comm. 2012). Ackerman et al. (2007) suggested, based on the fluid inclusion study and feldspars thermometry, that the amphibole-bearing pegmatite crystallized at $0.42-0.58 \mathrm{GPa}$ and $600-640{ }^{\circ} \mathrm{C}$ (Fig. 11). Such conditions are very similar to those for the regional metamorphism in the host Fe-skarn $\left(0.45-0.65 \mathrm{GPa}, 590-680^{\circ} \mathrm{C}\right.$ : Žáček 1997). This tectonometamorphic event very likely generated rather primitive anatectic melts of the host metapelitic rocks, which intruded the brittle Fe-skarn. Absence of amphibole-bearing pegmatites in the hybrid rock may suggest that the exchange reactions at the contact of the Fe-skarn and host gneisses and origin of the amphibole-bearing pegmatites (early stage of pegmatites evolution) were rather simultaneous processes. However, high variability of amphibole-bearing pegmatites (shape and size of pegmatite bodies, abundance and thickness of reaction rims, presence/absence of pockets and proportions of the individual minerals) imply fairly variable conditions for their origin such as rheology and temperature of the host rock, and availability of fluids during crystallization. Fluorite, an important accessory, minor to exceptionally major mineral in the amphibole-bearing pegmatites, crystallized during magmatic-hydrothermal transition (Ackerman 2005).

The amphibole-bearing Magdalena pegmatite with a large pocket lined with crystals of smoky quartz and feldspars differs from common pegmatites with pockets lined with crystals of smoky quartz, tourmaline and feldspars occurring typically in the Strážek Moldanubicum (Gadas et al. 2012). Absence of pegmatite textures (e.g., graphic intergrowths of Qz $+\mathrm{Kfs}$ ) and B-rich minerals (tourmalines, dumortierite) is typical of all amphibolebearing pegmatites cutting Fe-skarn in the Moldanubian Zone. Axinite and tourmaline are very rare or absent not only in Vlastějovice but also at other localities (e.g., Filip 2002; Filip et al. 2006; Novák and Cempírek 2010). Consequently, although amphibole-bearing pegmatites and common pegmatites with smoky quartz and tourmaline crystals in pockets are very likely anatectic in origin, they differ significantly in textures, chemical composition of melt (high $\mathrm{B}$ and $\mathrm{Al}$ in tourmaline-bearing pocket pegmatites) and mineralogy. 


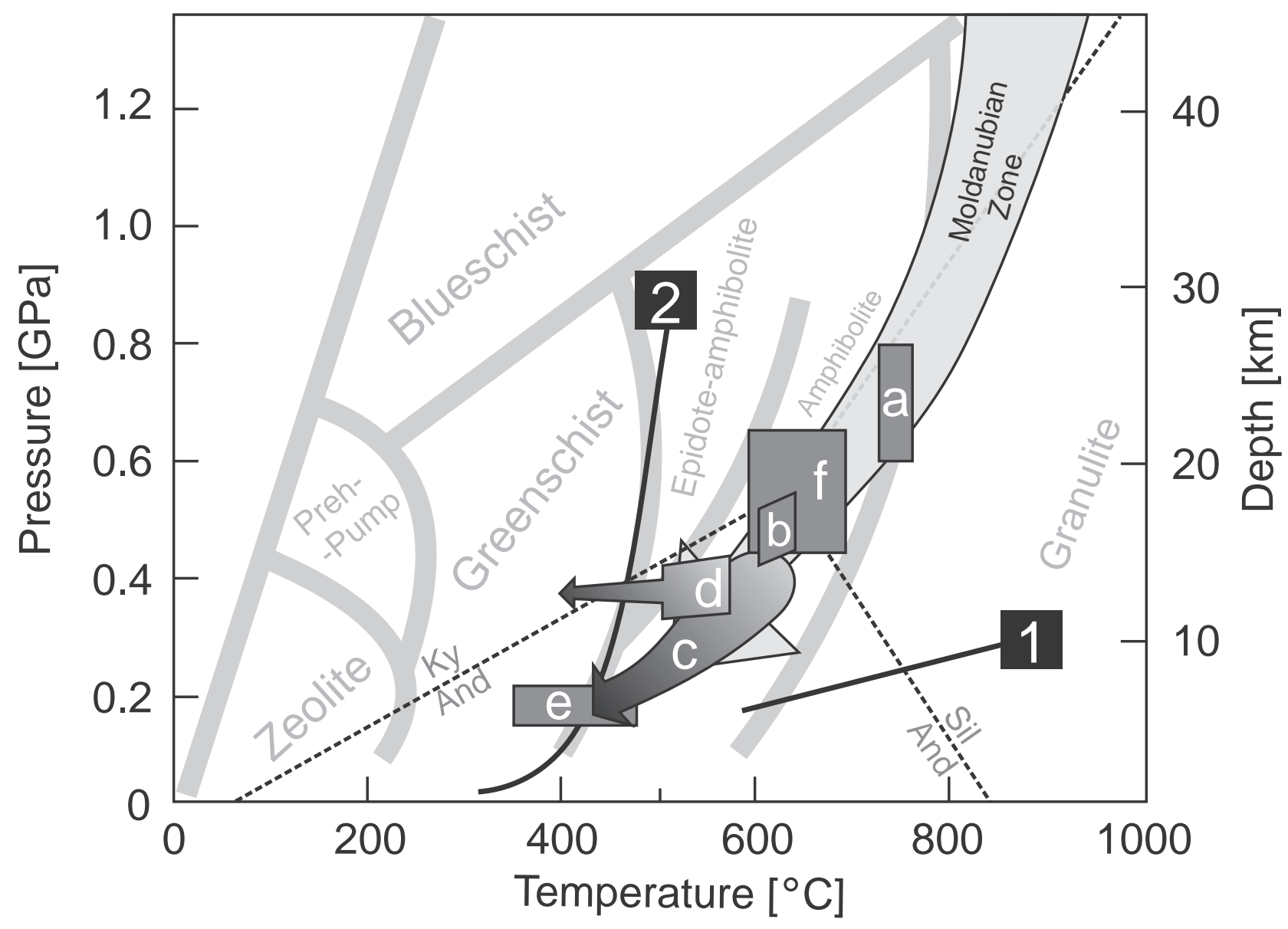

Fig. 11 P-T path in metamorphic rocks of the Moldanubian Zone (modified from Pertoldová et al. 2009 using the P-T-data from Tajčmanová et al. 2007; Kotková 2007 and Schulmann et al. 2008, 2009). The position of the $\mathrm{Al}_{2} \mathrm{SiO}_{5}$ triple point is from Pattison (1994), reaction 1: Alm + Als + $\mathrm{Qz}=\mathrm{Skn}$ (sekaninaite) (Mukhopadhyay and Holdaway 1994); reaction 2: Crd $+\mathrm{H}_{2} \mathrm{O}=\mathrm{Dsp}$ (Hemley et al. 1980). The positions of the individual pegmatites: a) borosilicates-bearing veinlet from the Bory Granulite Massif (Cempírek et al. 2010), b) amphibole-bearing pegmatites at Vlastějovice (Ackerman et al. 2007), c) common pegmatites with pockets from the Strážek Moldanubicum based on the data of Gadas et al. (2012), d) Elbaite pegmatite at Vlastějovice (Ackerman et al. 2007), e) discordant rare-element pegmatites with primary sekaninaite, andalusite and diaspore from the Bory-Hatě area, Bory Granulite Massif; f) P-T data of the MP-HT metamorphism from the Fe-skarn (Žáček 1997).

\subsection{Tourmaline-bearing granite-pegmatite system}

The granite and pegmatite bodies occurring in the Vlastějovice Fe-skarn represent a unique example of granite-pegmatite system, where the individual small pegmatite dikes show unambiguous relationship to the well-defined parts of the texturally heterogeneous parental granite body (Figs 5, 6a-b, d). Both examined tourmaline-bearing pegmatites from the paragneisses (Březina, Nosatá skála) were very likely related to the same magmatic event as the granite-pegmatite system cutting the Fe-skarn, although no explicit evidence is provided.

The Footwall granite-pegmatite is highly heterogeneous showing textural evolution from medium- to coarse-grained granite I, locally porphyritic (Tab. 1), through subhomogeneous coarse-grained granite II to coarse-grained granite III with large blocky K-feldspar crystals (Fig. 6e). The texturally most primitive part of the granite intrusion (granite I) generated rather irregular body of the Pegmatite No. 12 with subhomogeneous internal structure built solely by a coarse-grained granitic unit. Striking textural similarity with the granite I and brecciated style of emplacement into the host Fe-skarn (Fig. 6a) suggest that the Pegmatite No. 12 rather represents an apophysis of the granite I with no clear evidence for advanced fractionation. The more evolved Pegmatite No. 4 was derived from the granite II (Fig. 6b); it forms a homogeneous dike with a coarse-grained texture (Fig. 6c) resembling that of the parental granite II. The Spessartine pegmatite with simply zoned internal structure including graphic unit, rare blocky K-feldspars, minor albite unit and small blocks of quartz, was derived from the most 
evolved granite III (Fig. 6d). Generally, the pegmatite bodies cutting the Fe-skarn could be linked with the different parts of the Footwall granite-pegmatite body and show apparent relationship: texturally more evolved parental granite generated texturally and compositionally more evolved pegmatite.

Different degrees of geochemical fractionation of the individual pegmatite bodies are manifested by their mineral assemblages (Tab. 3); e.g., increasing amount of tourmaline relative to biotite (or amphibole), or presence of garnet in the Spessartine pegmatite and Li-bearing tourmaline in the most evolved Elbaite pegmatite. Clearly, also the amount of albite increases from primitive bodies in the paragneisses (Březina and Nosatá skála pegmatites) and in the Fe-skarn (Pegmatite No. 12 and Pegmatite No. 4), through the Spessartine pegmatite to the most evolved Elbaite pegmatite. The assemblages of accessory minerals illustrate the increased degree of fractionation in the Spessartine and Elbaite pegmatites as well; e.g. ilmenite and $\mathrm{Nb}$-rich rutile in the Spessartine pegmatite and columbite and pyrochlore-group minerals in the Elbaite pegmatite (see Tab. 3).

Different degrees of fractionation in the individual pegmatite bodies are also evident from the chemical composition of tourmalines (see Fig. 8a-b; Tab. 4), disregarding the overprint by $\mathrm{Ca}, \mathrm{Fe}$-contamination in the pegmatites cutting the Fe-skarn, where introduction of Fe into tourmalines significantly decreased the $\mathrm{Al}$ contents and $\mathrm{Mg} /(\mathrm{Mg}+\mathrm{Fe})$ ratios. Slightly higher concentrations of $\mathrm{F}$ in tourmaline (Tab. 4) from the pegmatites cutting the Fe-skarn relative to the pegmatites from paragneisses may be a product of contamination by the host Fe-skarn indicated by abundance of fluorite in the more contaminated amphibole-bearing pegmatites (Žáček et al. 2003; Ackerman 2005; Ackerman et al. 2007; Kadlec 2009; Novák and Cempírek 2010). However, higher contents of $\mathrm{F}$ in tourmaline may also be explained by crystal structure, chiefly high $\mathrm{Ca}$ and low vacancy in the X-site (Novák 2000; Henry and Dutrow 2011). Moderate to high F concentrations in elbaite to fluor-elbaite (Tab. 4) very likely imply higher degree of fractionation of the parental pegmatite melt enriched in $\mathrm{Li}, \mathrm{Be}, \mathrm{B}, \mathrm{F}, \mathrm{Mn}, \mathrm{Nb}$ and Ta (see Tab. 3).

The field evidence from the tourmaline-bearing pegmatites of the Vlastějovice region shows that the body of Footwall granite-pegmatite was parental to all tourmaline-bearing pegmatite dikes cutting the Fe-skarn (Figs 5,11). The existence of a larger concealed granite pluton, several $\mathrm{km}^{3}$ in size (see e.g, Baker 1998; London 2008), which would be related to this granite-pegmatite system, is not supported by any field observations or geophysical data. Intense mining works in the past also confirmed a small size and regional extent of the Footwall granite-pegmatite (Koutek 1950). Such a granite intrusion, however, is much smaller than is the size of potential granitic plutons fertile to granitic pegmatites commonly suggested (e.g., Černý 1991b; London 2008) or even modeled (Baker 1998). Hence, the Vlastějovice granite-pegmatite system is very unusual and raises the question, how granites parental to granitic pegmatites may vary in their size, shape, textures, compositions and spatial relations (see e.g., Černý 1991b; Martin and De Vito 2005; London 2008; Černý et al. 2012). Degrees of textural differentiation and fractionation of the individual tourmaline-bearing pegmatite dikes are comparable to those of the respective parts of their parental granite intrusion. They are also related to the shape of pegmatite bodies from an irregular brecciated Pegmatite no. 12 (Fig. 6a) to a thin and long dike of the evolved Spessartine pegmatite (Fig. 6d). These are rather consistent with the model of sequential derivation of pegmatite melts from evolving parental granite (London 2008). However, parental granite intrusion is very small and this implies thermal regime in its envelope different from large plutons. Thus the comparison between relatively voluminous plutons (e.g., Černý 1991b) and small Footwall granitepegmatite body from Vlastějovice as fertile granites is rather difficult.

\subsection{Positions of granitic pegmatites in the $P-T$ space}

The positions of the individual types of granitic pegmatites of the Moldanubian Zone in the P-T space (see Fig. 11) illustrate evident distinction between the Elbaite pegmatite from Vlastějovice and other rare-element granitic pegmatites. The pressure of $0.31-0.43 \mathrm{GPa}$ derived from the fluid inclusion study (Ackerman et al. 2007) is higher than that for the complex Moldanubian pegmatites, where the presence of primary petalite (or spodumene and quartz intergrowths after petalite), locally abundant andalusite and sekaninaite suggests pressures lower than c. 0.2-0.3 GPa (Novák 2005; Novák and Cempírek 2010). Whether it reflects different depth of pegmatite melt emplacement in the Vlastějovice region relative to other (more southerly) parts of the Moldanubian Zone (Strážek Moldanubicum, Jihlava region, Český Krumlov Unit) or overestimation of the pressure for the Elbaite pegmatite from Vlastějovice (Ackerman et al. 2007) is not clear.

The Fig. 11 shows the estimated P-T conditions for various granitic pegmatites from the Moldanubian Zone. It illustrates that primitive to highly evolved and typically B-rich pegmatites originated throughout much of the Variscan evolution from the medium- $(\sim 0.6-0.7 \mathrm{GPa}$; Cempírek et al. 2010) to the low-pressure conditions (less than 0.2 GPa in the Dolní Bory pegmatites, where common near end-member sekaninaite limits such low pressure). This trend is fairly consistent with the $\mathrm{P}-\mathrm{T}$ paths 
of the Variscan metamorphism in the Moldanubian Zone (Fig. 11) and indicates that formation of various granitic pegmatites was an integral part of the tectono-magmatic evolution of the region. Hence, granitic pegmatites and their minerals may be utilized in discussions of geological evolution of the region (e.g., Novák et al. 1998; Novák 2001, 2005; Melleton et al. 2012).

Acknowledgements. The authors are very grateful to the reviewers R. Skála and P. Uher as well as handling editor S. Vrána and editor-in-chief V. Janoušek for constructive criticism that significantly improved the manuscript. We are also indebted to S. Houzar for critical reading of the manuscript. This work was supported by the research project GAČR P210/10/0743 to MN a PG.

\section{References}

ACKerman L (2005) Magmatic vs. hydrothermal origin of fluorites from Vlastějovice, Bohemian Massif. J Czech Geol Soc 50: 35-41

Ackerman L, Zachariáš J, Pudilová M (2007) P-T and fluid evolution of barren and lithium pegmatites from Vlastějovice, Bohemian Massif, Czech Republic. Int J Earth Sci 96: 623-638

Bačík P, Cempírek J, Uher P, Novák M, Ozdín D, ŠKoda R, Breiter K, Klementová M, Duuďa R, Groat la (2013) Oxy-schorl, $\mathrm{Na}\left(\mathrm{Fe}_{2}{ }_{2}^{2+} \mathrm{Al}\right) \mathrm{Al}_{6} \mathrm{Si}_{6} \mathrm{O}_{18}\left(\mathrm{BO}_{3}\right)_{3}(\mathrm{OH})_{3} \mathrm{O}$, a new mineral from Zlatá Idka, Slovak Republic and Přibyslavice, Czech Republic. Amer Miner 98: 485-492

BAKER DR (1998) The escape of pegmatite dikes from granitic plutons: constraints from new models of viscosity and dike propagation. Canad Mineral 36: 255-263

Brabec P (2002) Antimony mineralization in Vlastějovice. Unpublished MSci. Thesis, Charles University, Prague, pp 1-128 (in Czech)

Breiter K, Scharbert S (1995) The Homolka magmatic centre - an example of late Variscan ore bearing magmatism in the South Bohemian Batholith (southern Bohemia, northern Austria). Jb Geol B-A 138: 9-25

Breiter K, Scharbert S (1998) Latest intrusions of the Eisgarn Pluton (South Bohemia - Northern Waldviertel). Jb Geol B-A 141: 25-37

Breiter K, Čopjaková R, Gabašová A, ŠKoda R (2005a) Chemistry and mineralogy of orthogneisses in the northeastern part of the Moldanubicum. J Czech Geol Soc 50: 81-94

Breiter K, Novák M, Koller F, Cempírek J (2005b) Phosphorus - an omnipresent minor element in garnet of diverse textural types from leucocratic granitic rocks. Mineral Petrol 85: 205-221

BuriáneK D, Novék M (2004) Morphological and compositional evolution of tourmaline from nodular granite at Lavičky near Velké Meziříčí, Moldanubicum, Czech Republic. J Czech Geol Soc 49: 81-90

BuriáneK D, NovÁK M (2007) Compositional evolution and substitutions in disseminated and nodular tourmaline from leucocratic granites: examples from the Bohemian Massif, Czech Republic. Lithos 95: 148-164

Carswell DA, O'Brien PJ (1993) Thermobarometry and geotectonic significance of high pressure granulites: examples from the Moldanubian Zone of the Bohemian Massif in Lower Austria. J Petrol 34: 427-459

Cempírek J, NovÁk M (2004) Dumortierite and tourmaline from abyssal pegmatites from Vémyslice near Moravský Krumlov, Gföhl Unit, Moldanubicum. Acta Mus Moraviae, Sci Geol 89: 45-54 (in Czech)

Cempírex J, Novák M (2006) Mineralogy of dumortieritebearing abyssal pegmatites at Starkoč and Běstvina, Kutná Hora Crystalline Complex. J Czech Geol Soc 51: $259-270$

Cempírek J, Novák M, Vávra V (1999) Hurlbutite from beryl-columbite pegmatite in Kostelní Vydří near Telč, western Moravia. Acta Mus Moraviae, Sci Geol 84: 45-48 (in Czech)

Cempírek J, Novák M, Ertl, A, Hughes JM, Rossman GR, DYAR MD (2006) Fe-bearing olenite with tetrahedrally coordinated $\mathrm{Al}$ from an abyssal pegmatite at Kutná Hora, Czech Republic: structure, crystal chemistry, optical spectra and XANES spectra. Canad Mineral 44: 23-30

Cempírek J, Novák M, Dolníček Z, Kotková J, Škoda R (2010) Crystal chemistry and origin of grandidierite, ominelite, boralsilite and werdingite from the Bory Granulite Massif, Czech Republic. Amer Miner 95: 1533-1547

Chen F, Siebel W (2004) Zircon and titanite geochronology of the Fürstenstein granite massif, Bavarian Forest, NW Bohemian Massif: pulses of the late Variscan magmatic activity. Eur J Mineral 16: 777-788

COOKE RA, O'BRIEN PJ (2001) Resolving the relationship between high $\mathrm{P}-\mathrm{T}$ rocks and gneisses in collisional terranes: an example from the Gföhl gneiss-granulite association in the Moldanubian Zone, Austria. Lithos 58: 33-54

ČECH F (1985) Mineralogy of granitic pegmatites in the Czech part of the Bohemian Massif. Unpublished DrSci. Thesis, Charles University, Prague, pp 1-333 (in Czech) Čéth F, StanĚK J, DÁvidová Š (1981) Minerals of pegmatites. In: BERNARD JH (ed) Mineralogy of Czechoslovakia. Academia, Prague, pp 98-183 (in Czech)

ČERNÝ P (1991a) Rare-element granitic pegmatites. I. Anatomy and internal evolution of pegmatite deposits. Geosci Canada 18: 49-67

ČERNÝ P (1991b) Rare-element granitic pegmatites. II. Regional to global environments and petrogenesis. Geosci Canada 18: 68-81

ČERnÝ P, ERCiT TS (2005) The classification of granitic pegmatites revisited. Canad Mineral 43: 2005-2026 
Černý P, StaněK J, Novák M, BaAstgaard H, Rieder M, Ottolini L, Kavalová M, Chapman R (1995) Chemical and structural evolution of micas at the Rožná and Dobrá Voda pegmatites, Czech Republic. Mineral Petrol 55: 177-202

Černý P, Chapman R, Schreyer W, Ottolini L, Bottazzi P, McCAmmon C (1997) Lithium in sekaninaite from the type locality, Dolní Bory, Czech Republic. Canad Mineral 35: 167-173

ČERnÝ P, NovÁK M, CHAPMAN R (2000) Subsolidus behavior of niobian rutile from Věžná, Czech Republic: a model for exsolution in phases with $\mathrm{Fe}^{2+}>>\mathrm{Fe}^{3+}$. J Czech Geol Soc 45: 21-35

Černý P, Chapman R, Teertstra DK, Novák M (2003) Rubidium- and cesium-dominant micas in granitic pegmatites. Amer Miner 88: 1832-1835

Černý P, NovÁk M, Chapman R, Ferreira KJ (2007) Subsolidus behavior of niobian rutile from Písek region, Czech Republic: a model for exsolution in $\mathrm{W}$ - and $\mathrm{Fe}^{2+}>>\mathrm{Fe}^{3+}$-rich phases. J Geosci 52: 143-159

ČERnÝ P, London D, NovÁK M (2012) Granitic pegmatites as reflections of their sources. Elements 8: 289-294

ČUJAN J (1966) Occurrence of large crystals of smoky quartz at the skarn deposit Vlastějovice NWN of Ledeč nad Sázavou. Čas Nár Muz, Odd př́rodověd 135: 232-233 (in Czech)

Dill HG, ŠKoda R, Weber B, Berner ZA, Müller A, BaKKER RJ (2012) A newly discovered swarm of shear-zonehosted $\mathrm{Bi}-\mathrm{As}-\mathrm{Fe}-\mathrm{Mg}-\mathrm{P}$-rich aplites and pegmatites in the Hagendorf-Pleystein pegmatite province, southeastern Germany: a step closer to the metamorphic root of pegmatites. Canad Mineral 50: 943-974

Dobeš M, Pokorný L (1988) Gravimetry applied to the interpretation of the morphology of the Čertovo břemeno durbachite body in the Central Bohemian Pluton. Věst Ústř úst geol 63: 129-135 (in Czech)

Ertl A, Schuster R, Prowatke S, Brandstätter F, Ludwig T, Berndhardt H-J, Koller F, Hughes JM (2004) Mnrich tourmaline and fluorapatite in a Variscan pegmatite from Eibenstein an der Thaya, Bohemian Massif, Lower Austria. Eur J Mineral 16: 551-560

Ertl A, Rossman GR, Hughes JM, Prowatke S, Ludwig T (2005) Mn-bearing "oxy-rossmanite" with tetrahedrally coordinated Al and B from Austria: structure, chemistry, and infrared and optical spectroscopic study. Amer Miner 90: 481-487

Ertl A, Schuster R, Hughes JM, Ludwig T, Meyer H-P, Finger F, Dyar MD, Ruschel K, Rossman GR, Klötzli U, Brandstätter F, Lengauer CL, Tillmanns E (2012) Li-bearing tourmalines in Variscan pegmatites from the Moldanubian nappes, Lower Austria. Eur J Mineral 24: 695-715

Fiala J, Fuchs G, Wendt JI (1995) Stratigraphy of the Moldanubian Zone. In: Dallmeyer RD, Franke W, We-
BER K (eds) Pre-Permian Geology of Central and Eastern Europe. Springer-Verlag, Berlin, pp 417-428

Fiala J, MatěJovská O, VaňKová V (1987) Moldanubian granulites: source material and petrogenetic considerations. Neu Jb Mineral, Abh 157: 133-165

Filip J (2002) Mineral assemblages and chemical composition of axinite from selected rocks of the Bohemian Massif. Unpublished MSci Thesis, Masaryk University, Brno, pp 1-69 (in Czech)

Filip J, Kolitsch U, Novák M, Schneewiess O (2006) The crystal structure of near-end-member ferroaxinite from an iron-contaminated primitive pegmatite at Malešov, Czech Republic. Canad Mineral 44: 1159-1170

Finger F, Roberts MP, Haunschmid B, Schermaier A, SteyRER HP (1997) Variscan granitoids of Central Europe: their typology, potential sources and tectonothermal relations. Mineral Petrol 61: 67-96

Finger F, Gerdes A, Janoušek V, René M, Riegler G (2007) Resolving the Variscan evolution of the Moldanubian sector of the Bohemian Massif: the significance of the Bavarian and the Moravo-Moldanubian tectonometamorphic phases. J Geosci 52: 9-28

Friedl G, Finger F, Paquette JL, von Quadt A, McNaughTON NJ, Fletcher IR (2004) Pre-Variscan geological events in the Austrian part of the Bohemian Massif deduced from $\mathrm{U} / \mathrm{Pb}$ zircon ages. Int $\mathrm{J}$ Earth Sci (Geol Rundsch) 93: 802-823

Fuchs G, Matura A (1976) Zur Geologie des Kristallins der südlichen Böhmischen Masse. Jb Geol B-A 119: 1-43

Gadas P, Novák M, StanĚK J, Filip J, Vašinová Galiová M (2012) Compositional evolution of zoned tourmaline crystals from pockets in common pegmatites, the Moldanubian Zone, Czech Republic. Canad Mineral 50: 895-912

Gerdes A, Wörner G, Henk A (2000) Post-collisional granite generation and HT-LP metamorphism by radiogenic heating: the Variscan South Bohemian Batholith. J Geol Soc, London 157: 577-587

Gerdes A, Friedl G, Parrish RR, Finger F (2003) High resolution geochronology of Variscan granite emplacement - the South Bohemian Batholith. J Czech Geol Soc 48: 53-54

Ginzburg AI, Timofejev IN, Feldman LG (1979) Principles of Geology of the Granitic Pegmatites. Nedra, Moscow, pp 1-296 (in Russian)

GolıÁš V (2002) Thorium occurrences in the Czech Republic and their mineralogy. In: KŘíBEK B, ZEMAN J (eds) Uranium Deposits - From Their Genesis to the Environmental Aspects. Czech Geological Survey, Prague, pp 53-56

Hasalová P, Schulmann K, Lexa O, Štípská P, Hrouda F, Ulrich S, Haloda J, TÝcová P (2008) Origin of migmatites by deformation enhanced melt infiltration of orthogneiss: a new model based on quantitative microstructural analysis. J Metamorph Geol 26: 29-53 
Hemley JJ, Montoya JW, Marinenko JW, Luce RW (1980) Equilibria in the system $\mathrm{Al}_{2} \mathrm{O}_{3}-\mathrm{SiO}_{2}-\mathrm{H}_{2} \mathrm{O}$ and some general implications for alteration/mineralization processes. Econ Geol 75: 210-228

HenRy DJ, Dutrow LB (2011) The incorporation of fluorine in tourmaline: internal crystallographic controls or external influences? Canad Mineral 49: 41-56

Henry D, Novák M, Hawthorne FC, Ertl A, Dutrow B, Uher P, Pezzotta F (2011) Nomenclature of the tourmaline-supergroup minerals. Amer Miner 96: 895-913

Holub FV (1997) Ultrapotassic plutonic rocks of the durbachite series in the Bohemian Massif: petrology, geochemistry and petrogenetic interpretation. Sbor geol Věd, ložisk Geol Mineral 31: 5-26

Holub FV, KleČKa M, MatěJKa D (1995) Igneous activity of the Moldanubian Zone. In: Dallmeyer RD, Franke W, Weber K (eds) Pre-Permian Geology of Central and Eastern Europe. Springer, Berlin, pp 444-452

Holub FV, Machart J, Manová M (1997a) The Central Bohemian Plutonic Complex: geology, chemical composition and genetic interpretation. Sbor geol Věd, ložisk Geol Mineral 31: 27-50

Holub FV, Cocherie A, Rossi P (1997b) Radiometric dating of granitic rocks from the Central Bohemian Plutonic Complex (Czech Republic): constraints on the chronology of thermal and tectonic events along the Moldanubian-Barrandian boundary. CR Acad Sci Paris IIa 325: 19-26

HouZar S, KadLEC T, SEJKORA J (2009) Occurrence of wollastonite in skarn from Vlastějovice, Central Bohemia (Czech Republic). Bull mineral-petrolog Odd Nár Muz (Praha) 17: 34-40 (in Czech)

Hönig S, Leichmann J, Novák M (2010) Unidirectional solidification textures and garnet layering in Y-enriched garnet-bearing aplite-pegmatites in the Cadomian Brno Batholith, Czech Republic. J Geosci 55: 81-97

JANOUŠEK V, GERDES A (2003) Timing the magmatic activity within the Central Bohemian Pluton, Czech Republic: conventional U-Pb ages for the Sázava and Tábor intrusions and their geotectonic significance. J Czech Geol Soc 48: 70-71

JANOUŠEK V, HoluB FV (2007) The causal link between HPHT metamorphism and ultrapotassic magmatism in collisional orogens: case study from the Moldanubian Zone of the Bohemian Massif. Proc Geol Assoc 118: 75-86

Janoušek V, Bowes DR, Rogers G, Farrow CM, Jelínek E (2000) Modelling diverse processes in the petrogenesis of a composite batholith: the Central Bohemian Pluton, Central European Hercynides. J Petrol 41: 511-543

KADLEC T (2007a) Tourmaline as an indicator of degree of contamination in granitic pegmatites from Vlastějovice near Sázava. Unpublished MSci. Thesis, Masaryk University, Brno, pp 1-77 (in Czech)

Kadlec T (2007b) Datolite from Vlastějovice. Minerál 6: 505-507 (in Czech)
KADLEC T (2009) Chemical composition of tourmaline from granitic pegmatites cutting Fe-skarn and gneisses in Vlastějovice; role of host rock on composition of tourmaline (contamination). Unpublished Doctoral (RNDr.) Thesis, Masaryk University, Brno, pp 1-95 (in Czech)

Kadlec T (2010) Revision of large pegmatite pocket in Vlastějovice. Minerál 6: 505-510 (in Czech)

KADLEC T (2012) A new occurrence of large crystal of datolite in Vlastějovice. Minerál 3: 203-205 (in Czech)

KlečKa M, Machart J, Pivec E (1992) Locality No. 10: Křížovská hora quarry near Vlašim, a Pre-Variscan tourmaline-bearing two-mica orthogneiss (Blaník type). In: NovÁK M, ČERnÝ P (eds) Lepidolite 200, Field Trip Guidebook. Masaryk University and Moravian Museum, Brno, pp 69-74

KoткоvÁ J (2007) High-pressure granulites of the Bohemian Massif: recent advances and open questions. J Geosci 52: 45-71

Kotková J, Schaltegger U, Leichmann J (2010) Two types of ultrapotassic plutonic ocks in the Bohemian Massif-coeval intrusions at different crustal levels. Lithos 115: 163-176

Kouteк J (1950) Magnetite ore deposit of skarn type from Vlastějovice v Posázaví. Rozpr Čs Akad Věd, R mat prír Věd 60: 1-30 (in Czech)

Koutek J, ŽÁ L (1953) Epigenetic antimony ores in the magnetite skarn deposit in Vlastějovice v Posázaví. Sbor Ústř Úst geol Odd geol 20: 593-612 (in Czech)

Kröner A, O'Brien PJ, Nemchin AA, Pidgeon RT (2000) Zircon ages for high pressure granulites from South Bohemia, Czech Republic, and their connection to Carboniferous high temperature processes. Contrib Mineral Petrol 138: 127-142

Kusiak MA, Dunkley DJ, Suzuki K, Kachlík V, KęDzior A, LeKKi J, Opluštil S (2010) Chemical (non-isotopic) and isotopic dating of Phanerozoic zircon. A case study of durbachite from the Třebíč Pluton, Bohemian Massif. Gondwana Res 17: 153-161

Leake Be, Wooley AR, Arps CeS, Birch WD, Gilbert MC, Grice JD, Hawthorne FC, Kato FC, Kisch HJ, Krivovichev VG, Linthout K, Laird J, Mandarino JA, Maresch WV, Nickel EH, Rock NMS, Schumacher JC, Smith DC, Stephenson NC N, Ungaretti L, Whittaker EJW, Guo Y (1997) Nomenclature of amphiboles: report of the Subcommittee on Amphiboles of the International Mineralogical Association on New Minerals and Mineral Names. Canad Mineral 35: 219-246

Liew TC, Finger F, Höск V (1989) The Moldanubian granitoid plutons of Austria: chemical and isotopic studies bearing on their environmental setting. Chem Geol 76: 41-55

London D (2008) Pegmatites. The Canadian Mineralogist, Special Publications 10: pp 1-347

Martin RF, De Vito C (2005) The patterns of enrichment in felsic pegmatites ultimately depend on tectonic setting. Canad Mineral 43: 2027-2048 
Matte P, Maluski H, Rajlich P, Franke W (1990) Terrane boundaries in the Bohemian Massif: result of large-scale Variscan shearing. Tectonophysics 177: 151-170

Melleton J, Gloaguen E, Frei D, Novák M, Breiter K (2012) How are the time of emplacement of rare-element pegmatites, regional metamorphism and magmatism interrelated in the Moldanubian Domain of Variscan Bohemian Massif, Czech Republic? Canad Mineral 50: 1751-1773

MrÁzeK Z, Vrána S (1984) Highly aluminian titanite from a plagioclase-fluorite pegmatite in skarn at Vlastějovice, Czechoslovakia. Neu Jb Mineral, Mh 6: 251-256

Mücke A, Keck E, HaAse J (1990) Die genetische Entwicklung des Pegmatits von Hagendorf-Süd/Oberpfalz. Aufschluss 41: 33-51

Mukhopadhyay B, Holdaway M (1994) Cordierite-garnet-sillimanite-quartz equilibrium. I. New experimental calibration in the system $\mathrm{FeO}-\mathrm{Al}_{2} \mathrm{O}_{3}-\mathrm{SiO}_{2}-\mathrm{H}_{2} \mathrm{O}$ and certain $\mathrm{P}-\mathrm{T}-\mathrm{X}\left(\mathrm{H}_{2} \mathrm{O}\right)$ reactions. Contrib Mineral Petrol 116: 462-472

NĚMEC D (1963) Eruptivgesteine in westmährischen Skarnen und ihre genetische Stellung. Neu Jb Mineral, Abh 100: 203-224

NĚMEC D (1989) Lithium aluminosilicates in pegmatites affected by stress. Chem Erde 49: 167-172

NĚMEC D (1990) Neues zur Mineralogie eines Hambergitführenden Pegmatitegangs von Kracovice (bei Třebíč, Westmorava, ČSFR). Z geol Wiss 18: 1105-1115

NovÁk M (1981) Mineralogy of pegmatite from Hamry nad Sázavou, Western Moravia. Acta Mus Moraviae, Sci nat 66: 7-16 (in Czech)

NovÁk M (2000) Compositional pathways of tourmaline evolution during primary (magmatic) crystallization in complex (Li) pegmatites of the Moldanubicum, Czech Republic. Mem Soc Ital Sci Natur Mus Civ Stor Natur Milano 30: 45-56

NovÁk M (2001) Are granitic pegmatites a toy for descriptive mineralogists or a useful tool for geologists? Mitt Österr Miner Ges 146: 217-219

NovÁK M (2005) Granitic pegmatites of the Bohemian Massif (Czech Republic); mineralogical, geochemical and regional classification and geological significance. Acta Mus Moraviae, Sci geol 90: 3-75 (in Czech).

NovÁk M (2007) Contamination in granitic pegmatites, examples from the Moldanubicum, Czech Republic. In: Martins T, Vieira R (eds) Granitic Pegmatites: the state of the Art - International Symposium, Book of Abstracts. Univ Porto, Facul Ciências Mem 8: 9-12

NovÁk M, Cempírek J (eds) (2010) Granitic pegmatites and mineralogical museums in Czech Republic. IMA 2010 Field Trip Guide CZ2. Acta Mineral Petrogr Field Guide Series 6, Szeged, pp 1-56

NovÁk M, FILIP J (2010) Unusual (Na,Mg)-enriched beryl and its breakdown products (beryl II, bazzite, bavenite) from euxenite-type NYF pegmatite related to the orogenic ultrapotassic Třebíč Pluton, Czech Republic. Canad Mineral 48: 615-628

NovÁk M, HYrŠL J (1992) Locality No. 3: Vlastějovice near Zruč nad Sázavou, pegmatites with fluorite penetrating skarn. In: NovÁK M, ČERnÝ P (eds) Lepidolite 200, Field Trip Guidebook. Masaryk University and Moravian Museum, Brno, pp 33-37

NovÁk M, Povondra P (1995) Elbaite pegmatites in the Moldanubicum: a new subtype of the rare-element class. Mineral Petrol 55: 159-176

NovÁk M, TAYLOR MC (2000) Foitite: formation during late stages of evolution of complex pegmatites at Dobrá Voda, Czech Republic, and Pala, California, USA. Canad Mineral 38: 1399-1408

NovÁK M, ČernÝ P, ČECh F, StAnĚK J (1992) Granitic pegmatites in the territory of the Bohemian and Moravian Moldanubicum. In: NovÁK M, ČERnÝ P (eds) Lepidolite 200, Field Trip Guidebook. Masaryk University and Moravian Museum, Brno, pp 11-20

Novák M, ČErný P, Kimbrough DL, Taylor MC, Ercit TS (1998) $\mathrm{U}-\mathrm{Pb}$ ages of monazite from granitic pegmatites in the Moldanubian Zone and their geological implications. Acta Univ Carol, Geol 42: 309-310

NovÁk M, Selway JB, Černý P, Hawthorne FC, Ottolini L (1999a) Tourmaline of the elbaite-dravite series from an elbaite-subtype pegmatite at Bližná, southern Bohemia, Czech Republic. Eur J Mineral 11: 557-568

Novák M, Černý P, Cooper M, Hawthorne FC, Ottolini L, Xu Z, Liang J-J (1999b) Boron-bearing 2M polylithionite and $2 \mathrm{M}_{1}+1 \mathrm{M}$ boromuscovite from an elbaite pegmatite at Řečice, western Moravia, Czech Republic. Eur J Miner 11: 669-678

Novák M, Povondra P, Selway JB (2004) Schorl-oxyschorl to dravite-oxy-dravite tourmaline from granitic pegmatites; examples from the Moldanubicum, Czech Republic. Eur J Mineral 16: 323-333

NovÁk M, Johan Z, ŠKoda R, ČERnÝ P, Šrein V, Veselovský $\mathrm{F}$ (2008) Primary oxide minerals in the system $\mathrm{WO}_{3}-$ $\mathrm{Nb}_{2} \mathrm{O}_{5}-\mathrm{TiO}_{2}-\mathrm{Fe}_{2} \mathrm{O}_{3}-\mathrm{FeO}$ and their breakdown products from the pegmatite No. 3 at Dolní Bory-Hatě, Czech Republic. Eur J Mineral 20: 487-499

Novák M, Škoda R, Filip J, Macek I, Vaculovič T (2011) Compositional trends in tourmaline from the intragranitic NYF pegmatites of the Třebíč Pluton, Czech Republic; electron microprobe, LA-ICP-MS and Mössbauer study. Canad Mineral 49: 359-380

Novák M, ŠKoda R, Gadas P, Krmíček L, ČERnÝ P (2012) Contrasting origins of the mixed signature in granitic pegmatites; examples from the Moldanubian Zone, Czech Republic. Canad Mineral 50: 1077-1094

Novák M, Ertl A, Povondra P, Vašinová Galiová M, Rossman GR, Pristacz H, Prem M, Giester G, GADAS P, ŠKODA R (in print) Darrellhenryite, $\mathrm{Na}\left(\mathrm{LiAl}_{2}\right)$ 
$\mathrm{Al}_{6}\left(\mathrm{BO}_{3}\right)_{3} \mathrm{Si}_{6} \mathrm{O}_{18}(\mathrm{OH})_{3} \mathrm{O}$, a new mineral from the tourmaline supergroup. Amer Miner 98.

O'Brien PJ, RötZler J (2003) High-pressure granulites: formation, recovery of peak conditions and implications for tectonics. J Metamorph Geol 21: 3-20

PatTison DRM (1994) Stability of andalusite and sillimanite and the triple point: constraints from the Ballachulish aureole, Scotland. J Geol 100: 423-446

Pavlíček V, Breiter K, Škoda R (2009) Pegmatite of beryl-columbite type from Šejby, Novohradské hory Highland, Czech Republic. Zpr Geol Výzk za r 2008: 185-189 (in Czech)

Pertoldová J, Týcová P, Verner K, Košuličová M, Pertold Z, Košler J, Konopásek J, Pudilová M (2009) Metamorphic history of skarns, origin of their protolith and implications for genetic interpretation; an example from three units of the Bohemian Massif. J Geosci 54: 101-134

Pertoldová J, Verner K, VRána S, Buriánek D, Štědrá V, Vondrovic D (2010) Comparison of lithology and tectonometamorphic evolution of units at the northern margin of the Moldanubian Zone: implications for geodynamic evolution in the northeastern part of the Bohemian Massif. J Geosci 55: 299-319

РотUŽ́́k M (1996) Skarn on the Holý vrch in Vlastějovice. Unpublished MSci. Thesis, Charles University, Prague, pp 1-138 (in Czech)

Pouchou JL, Pichoir F (1985) "PAP" $(\phi-\rho-Z)$ procedure for improved quantitative microanalysis. In: ARMSTRONG JT (ed) Microbeam Analysis. San Francisco Press, pp 104-106

POVONDRA P (1981) The crystal chemistry of tourmalines of the schorl-dravite series. Acta Univ Carol, Geol 1981: 223-264

PoVONDRA P (1989) Geochemistry of micas from pegmatites and other rocks of the Bechyně orthogneissoid. Acta Univ Carol, Geol 1989: 127-138

Povondra P, VRána S (1996) Tourmaline and associated minerals in alkali-feldspar orthogneiss near Hluboká nad Vltavou. J Czech Geol Soc 41: 191-200

Povondra P, ČECH F, STANĚK J (1985) Crystal chemistry of elbaites from some pegmatites of the Czech Massif. Acta Univ Carol, Geol 1985: 1-24

Povondra P, Pivec E, Č́ech F, Lang M, Novák F, Prachař I, UlRYCH J (1987) Přibyslavice peraluminous granite. Acta Univ Carol, Geol 1987: 183-283

Povondra P, StaňKová J, StaněK J (1992) $\mathrm{CO}_{2}$-bearing cordierite of Moldanubian leptynite rock series from Horní Bory, Czech Republic. Acta Univ Carol, Geol 1992: 331-349

Povondra P, Lang M, Pivec E, Ulrych J (1998) Tourmaline from the Prribyslavice peraluminous alkali-feldspar granite, Czech Republic. J Czech Geol Soc 43: 3-8

Rezek K, Kryst P (1985) Preliminary report on the occurrence of $\mathrm{U}-\mathrm{Th}, \mathrm{Ti}-\mathrm{Zr}$ and $\mathrm{Nb}-\mathrm{Ta}$ minerals in pegmatite at Holý vrch near Vlastějovice, WSW of Ledeč nad Sázavou. Čas Mineral Geol 30: 434 (in Czech)

Schulmann K, Lexa O, Štípská P, Racek M, Tajčmanová L, Konopásek J, Edel JB, Peschler A, Lehmann J (2008) Vertical extrusion and horizontal channel flow of orogenic lower crust: key exhumation mechanisms in large hot orogens? J Metamorph Geol 26: 273-297

Schulmann K, Konopásek J, JanoušeK V, Lexa O, Lardeaux JM, Edel JB, ŠTíPSkÁ P, UlRich S (2009) An Andean type Palaeozoic convergence in the Bohemian Massif. C R Geosci 341: 266-286

SeLWAY JB (1999) Compositional evolution of tourmaline in granitic pegmatites. Unpublished $\mathrm{PhD}$. Thesis, University of Manitoba, Canada, pp 1-363

Selway JB, Novák M, Hawthorne FC, Černý P, Ottolini L, Kyser TK (1998) Rossmanite, $\square\left(\mathrm{LiAl}_{2}\right) \mathrm{Al}_{6}\left(\mathrm{Si}_{6} \mathrm{O}_{18}\right)$ $\left(\mathrm{BO}_{3}\right)_{3}(\mathrm{OH})_{4}$, a new alkali-deficient tourmaline: description and crystal structure. Amer Miner 83: 896-900

Selway JB, Novák M, Černý P, Hawthorne FC (1999) Compositional evolution of tourmaline in lepidolite-subtype pegmatites. Eur J Mineral 11: 569-584

Siebel W (1995) Anticorrelated Rb-Sr and K-Ar age discordances: Leuchtenberg granite, NE Bavaria, Germany. Contrib Mineral Petrol 120: 197-211

Staněr J, Schnorrer G (1983) Phenakit und Buergerit aus dem Skarnsteinbruch Vlastějovice bei Zruč nad Sázavou in Böhmen. Aufschluss 44: 161-164

SYKA J (1990) Geological situation of the Vlastějovice deposit. Unpublished MSci. Thesis, Charles University, Prague, pp 1-91(in Czech)

Š́oda R, Novék M (2004) Accessory Nb-Ta-Ti minerals from the pegmatite in the Drahonín uranium mine, Strážek Moldanubicum. Acta Mus Moraviae, Sci Geol 89: 55-66 (in Czech)

ŠKoda R, NovÁK M (2007) Y,REE,Nb,Ta,Ti-oxide $\left(\mathrm{AB}_{2} \mathrm{O}_{6}\right)$ minerals from REL-REE euxenite-subtype pegmatites of the Třebíc Pluton, Czech Republic; substitutions and fractionation trends. Lithos 95: 43-57

ŠKoda R, Novák M, Černý P, Černý P (2004) Complex Nb$\mathrm{Ta}-\mathrm{Ti}$ oxides from pegmatite in Vepice near Milevsko, Čertovo břemeno Massif. Bull mineral-petrolog Odd Nár Muz (Praha) 12: 182-185 (in Czech)

ŠKodA R, NovÁK M, CíchA J (2011) Uranium-niobium-rich alteration products after "písekite", an intimate mixture of Y, REE, Nb, Ta, Ti-oxide minerals from the Obrázek I pegmatite, Písek, Czech Republic. J Geosci 56: 317-325

ŠKoda R, Novák M, Houzar S (2006) Granitic NYF pegmatites of the Třebíc Pluton. Acta Mus Moraviae, Sci Geol 91: 129-176 (in Czech)

TajČmanová L, Konopásek J, Connolly JAD (2007) Diffusion-controlled development of silica-undersaturated domains in felsic granulites of the Bohemian Massif (Variscan belt of Central Europe). Contrib Mineral Petrol 153: $237-250$ 
TeErtstra DK, Černý P, NovÁK M (1995) Compositional and textural evolution of pollucite in rare-element pegmatites of the Moldanubicum. Mineral Petrol 55: 37-52

Timmerman MJ (2008) Palaeozoic Magmatism. In: McCAnn T (ed) The Geology of Central Europe, Precambrian and Palaeozoic, vol. 1. Geological Society, London, pp 665-748

TvrdÝ J (2000) Fluorapophyllite from Vlastějovice. Bull mineral-petrolog Odd Nár Muz (Praha) 8: 265-267 (in Czech)

VAVŘín I (1960) Pegmatites from the Magdalena skarn deposit. Unpublished MSci. Thesis, Charles University, Prague, pp 1-90 (in Czech)

VAVŘín I (1962) Pegmatites from the Magdalena skarn deposit near Vlastějovice nad Sázavou. Sbor Nár Muz (Praha) Ř B 18: 89-105 (in Czech)

VeLLMER C, WeDEPOHL KH(1994) Geochemical characterization and origin of granitoids from the South Bohemian Batholith in Lower Austria. Contrib Mineral Petrol 118: 13-32

Vlasov KA (1952) Textural-paragenetic classification of granitic pegmatites. Izv Akad Sci USSR ser Geol 1952: 30-44 (in Russian)

VRÁNA S, KRÖNER A (1995) Pb-Pb zircon ages for tourmaline alkali-feldspar orthogneiss from Hluboká nad Vltavou in southern Bohemia. J Czech Geol Soc 40: 127-135

VRÁNA S, ŠTĚDRÁ V, NAHOdILOVÁ R (2009) Geochemistry and petrology of high-pressure kyanite-garnet-albiteK-feldspar felsic gneisses and granulites from the Kutná Hora Complex, Bohemian Massif. J Geosci 54: 159-179

Wendt JI, Kröner A, Fiala J, Todt W (1993) Evidence from zircon dating for existence of approximately 2.1 Ga old crystalline basement in southern Bohemia, Czech Republic. Geol Rundsch 82: 42-50
Whitney DL, Evans BE (2010) Abbreviations for names of rock-forming minerals. Amer Miner 95: 185-187

ŽÁČEK V (1997) Compositional evolution of garnet in regionally metamorphosed Moldanubian skarn, Vlastějovice, Bohemia - evidence of the preservation of early stages pre-dating regional metamorphism. Věst Čes Geol Úst 72: 37-48

ŽÁČEK V (2007) Potassian hastingsite and potassichastingsite from garnet-hedenbergite skarn at Vlastějovice, Czech Republic. Neu Jb Mineral, Abh 184: 161-168

ŽÁČEK V, FIŠERA M (2001) Prehnite-apophyllite vein from Vlastějovice. Bull mineral-petrol odd Nár Muz (Praha) 9: 316-318 (in Czech)

ŽÁČEK V, POVONDRA P (1991) Crystal chemistry of minerals from skarn at Vlastějovice nad Sázavou. Acta Univ Carol, Geol 1991: 71-101

ŽÁček V, NovÁK M, Raimboult L, Zachariáš J, Ackerman L (2003) Locality No. 8: Vlastějovice near Ledeč nad Sázavou. Fe-skarn, barren fluorite pegmatite. In: NovÁK M (ed) International Symposium on Light Elements in Rock Forming Minerals (LERM), Nové Město na Moravě, June 2003, Field Trip Guidebook. Masaryk University, Brno, pp 61-70

ŽÁK J, Holub FV, Verner K (2005) Tectonic evolution of a continental magmatic arc from transpression in the upper crust to exhumation of mid-crustal orogenic root recorded by episodically emplaced plutons: the central Bohemian Plutonic Complex (Bohemian Massif). Int J Earth Sci (Geol Rundsch) 94: 385-400

Žák J, Kratinová Z, Trubač J, Janoušek V, Sláma J, Mrlina J (2011) Structure, emplacement, and tectonic setting of Late Devonian granitoid plutons in the Teplá-Barrandian Unit, Bohemian Massif. Int J Earth Sci 100: 1477-1495 
